\title{
Sino-Russian Relations: The Impact of Central Asian Energy Resources
}

\author{
Thomas Stephan Eder
}

\begin{abstract}
The following paper strives to (1) present the reader with the results of my preceding book on the subject (Eder 2014) and to (2) review the trends that had been predicted therein. It provides a concise analysis of the Sino-Russian relationship's history, an account of post-Soviet regional energy projects, and an analysis and interpretation of the mainland Chinese discourse on the impact of the Central Asian energy issue on this relationship. The issue has been broadly discussed as a possible source of friction since the global financial and economic crisis. Chinese authors predicted that a great deal of co-ordination and compromise would be needed because of Russian sensitivities but conveyed confidence that their country's 'inevitable' expansion of crucial energy relations would be manageable. The book thus predicted a successful handling of competing interests in the short term but still foresaw a challenge to the 'strategic partnership' through the gradually shifting power balance. Over the last 18 months, China has advanced even faster and more comprehensively than anticipated and already overshadows Russia. Now undergirded by a more substantial political strategy, it quietly but resolutely pushes Moscow (and all its schemes of post-Soviet re-integration) aside. Managing ensuing frustrations and more blatant counter-measures will likely test the resolve and aptitude of Chinese policy-makers earlier than expected.
\end{abstract}

Keywords: China, Russia, Sino-Russian relations, Central Asia, energy

prae sens
Eder, Thomas Stephan. "Sino-Russian Relations: The Impact of Central Asian Energy Resources.” In Vienna Journal of East Asian Studies, Volume 6, eds. Rudiger Frank, Ina Hein, Lukas Pokorny and Agnes Schick-Chen. Vienna: Prae-sens Verlag, 2014, pp. 35-73. https://doi.org/10.2478/vjeas-2014-0008 


\section{Introduction}

One and a half years ago I finished a study on the impact of shifts in the Central Asian (CA) energy sector on Sino-Russian relations (Eder 2014). This was done through the lens of the mainland Chinese academic discourse on the subject, following its winding path from 1997 to 2012. That discourse was contextualised by a short analysis of the historical phases of the Sino-Russian relationship and factual narration of relevant Sino-Russian, Sino-CA, and Russo-CA energy projects. Conclusions were drawn with the help of a neoclassical realist-perception theory model of analysis.

On the basis of the existing Western literature, one could discern two schools on the future of Sino-Russian relations: the 'alarmists' and the 'limitationists'. In short, the former expect an anti-Western alliance or even military bloc, the latter an imminent deterioration of relations and even confrontation. Both schools make important references to the 'CA factor'. 'Alarmists' see the Shanghai Cooperation Organisation (SCO) as a nucleus for a military alliance; 'limitationists' expect geopolitical competition over CA to break the 'strategic partnership' (Yu Bin 2007). Neither of the schools draws on Chinese language sources.

The analysis of the mainland Chinese academic discourse on the important energy aspect of the 'CA factor' shall therefore complement and refine the debate. Chinese international relations (IR) experts were found to, on the one hand, consistently demand compromise, concessions, and an appreciation of the Russian position in the region, and, on the other hand, increasingly underline the centrality of CA to Chinese energy security and the sheer impossibility of turning back. Therefore, I predicted successful prevention of conflict in the short-term (i.e. this decade) but a growing challenge to the 'strategic partnership' in the long-term, as Moscow perceives a gradual encroachment from the East and threats to its plans of reunification in the former Soviet space.

This paper serves as an update to the former study. It takes stock of the most recent developments, i.e. the time between June 2012 and December 2013, and will allow for a tentative first review of trends predicted by Chinese scholars and my earlier book. It shall suffice here to make only marginal notes on this relationship's history and provide a concise summary of energy projects up to this paper's period of investigation. 


\section{Setting up the chessboard: Contextualisation of the Chinese discourse}

\section{Sino-Russian history: Traumata and nostalgia}

The long and laden history of Sino-Russian relations can, despite all its complexities, be structured according to certain patterns. Among many other efforts to do so, two Chinese scholars have rather recently provided us with concise and helpful categorisation, Chén Lùlù 沈露璐 (2010: 88) and Yu Bin (2007: 59). Their convincing line of argumentation will be mostly followed here. Chén uses four patterns to describe all forms of contact between the two nations: (1) oppression; (2) alignment; (3) resistance; and (4) normalcy. Yu delineates only (1) hierarchy-encompassing the first three patterns in Chén's system - and (2) equality. Similar to Chén's last pattern, Yú describes the latter as a phase of 'normalisation' of the relationship, in the sense that it is no longer ideologically charged, but rather pragmatically oriented, and a 'normal' mixture of co-operative and competitive elements.

Covering the last millennium in bold strokes, both authors make out only one real phase of normalcy or equality, the current one beginning when the two sides started to reconcile their differences in the late 1980s. This is to say that the history of Sino-Russian relations is broadly, in all its twists and turns and variations, a history of hierarchy (Eder 2014:19-26).

In the beginning it is much more than hierarchy though, as the relationship starts with a civilisational trauma on both the Russian and the Chinese side. The older trauma (i.e. a phase of oppression) is the Russian one. It harks back to the 13thcentury Mongol invasion of what is now the Russian Federation (RF), described by Lo Bobo as Russia's 'Mongol complex' (2008: 18-19). Although it involves Mongols rather than Chinese and has to be traced back to a very distant past, this part of Russia's history is consequential in its connection-via 19th-century nationalist Russian literature - to current discussions of a 'yellow threat' or 'yellow peril' (i.e. China) that are very much present in (especially regional) Russian media. Prejudices about uncivilised, culturally inferior, as well as potentially aggressive and oppressive neighbours to the East persist.

The Chinese trauma is more recent, substantive, and comprehensive. It is the much-discussed 'century of humiliation' from the mid-19th to the mid-20th century that has been and still is the relentless driving force behind all efforts of 'national reconstruction'. The latter, in turn, has been the dominant theme behind all policies of both Nationalist and Communist governments since then. Tsarist Russia was part of the Opium Wars, several of the 'unequal treaties' that made China a 'semicolony' were signed with St. Petersburg (e.g. Treaty of Aigun 1858, Treaty of Běijīng 北京 1860, Treaty of Tarbagatai 1864), and an enormous mass of land-1.7 million $\mathrm{km}^{2}$ (Wilson 2004: 15; Yu Bin 2007: 60)—was handed over to the Russian 
Empire (Chén Lùlù 2010: 88; Lo 2008: 21; Schmidt-Glintzer 2001: 17; Wishnick 2001: 192). This has been the basis of Chinese distrust towards a perceived aggressor. It has also caused numerous border disputes, with continuing misgivings about the course of the border among the Chinese populace, and an on-going fear on the Russian side that Běijīng is eventually going to make an attempt to change it (Chén Lùlù 2010: 88; Lo 2008: 21-23).

On the other side of the emotional divide is a phase of alignment that is often described as the 'honeymoon', the intense co-operation between the Soviet Union (SU) and the People's Republic of China (PRC) from the latter's inception in 1949 to roughly 1960 (Chén Lùlù 2010: 88; Yú 2007: 58). This period was marked by Běijīng's 'leaning-to-one-side' foreign policy, the copying of the Soviet system, and enormous technological and financial help from Moscow. Nonetheless, the relationship remained very much hierarchical, with the SU demanding deference to its leadership of the Socialist bloc (Wilson 2004: 18). Earlier co-operation between the two Communist parties had laid the foundation for the inter-state honeymoon. The at times unreliable and insincere stance of Joseph Stalin (1878-1953) had, however, also sown the seeds of the ensuing 'break-up' (Chén Lùlù 2010: 88; Lo 2008: 24; Marciacq 2009: 15-16; Wilson 2004: 18).

The Sino-Soviet split happened gradually from about 1956 to 1963 and can be seen as a third and shared trauma that reawakened those of the past. It was a phase of resistance (cf. Chén Lùlù 2010: 88), when the weaker side (i.e. China) revolted against the hierarchical relationship. Ideological and personal differences between Máo Zédōng 毛泽东 (1893-1976) and Nikita Sergeyevich Khrushchev (18941971), disagreements over foreign policy and leadership, and a perception of divergent national interests culminated in the withdrawal of all Soviet experts in 1960 and the end of inter-party and inter-military co-operation in 1963 (Lo 2008: 25; Marciacq 2009: 15-16; Wilson 2004: 18-19). A massive mutual troop build-up along the border and concomitant paranoia, nuclear threats by Moscow, and actual bloody clashes in 1969, drove the PRC into the arms of the Richard Nixon (1913-1994) administration and led to the US president's 1972 visit (Cheng 2009: 146; Lo 2008: 26; Wilson 2004: 19).

Eventually, though, the two nations made it back from the brink and the 'other Cold War' came to an end. This was based on new foreign policy priorities under Dèng Xiăopíng 邓小平 (Cabestan 2009: 64), precipitated by demilitarisation talks and ideological détente in 1979 (Wilson 2004: 19; Wishnick 2001: 115), which found clear expressions in Gorbachev's seminal speech on the two countries' relationship in Vladivostok in 1986 and his visit to Běijīng in 1989 (Chén Lùlù 2010: 88; Lo 2008: 27-28; Wilson 2004: 20-21; Yú 2007: 64). The two sides managed to de-ideologise their relations (Wishnick 2001: 110) and to weather regime change in Moscow (Wilson 2004: 24; Yú 2007: 65), to delineate their border (Wishnick 2001: 116, 122), and eventually even conclude a 'strategic partnership' agreement in 1996 
(Wilson 2004: 29-30; Wishnick 2001: 128-129). In the process, hierarchy was at long last replaced by equality (cf. Yú 2007: 58)—Jeanne L. Wilson (2004: 37) puts the point somewhere around the turn of the century - and a state of normalcy declared (cf. Chén Lùlù 2010: 88).

Despite the lip service that is being paid to the continuous equal partnership by both governments, it has become clear that not only is the PRC now the stronger partner, but also that the gap between the two is going to keep growing. This is going to challenge their 'strategic partnership', especially where the now overpowering China is going to insert itself into regions that Russia has come to view as its sphere of influence or 'backyard'. A new phase of hierarchy is beckoning and it will be important how both governments are going to manage this reality. In the following, one particularly challenging aspect, the CA energy sector, will be discussed.

\title{
Sino-Russian energy projects: Timing and other issues
}

\begin{abstract}
Energy, perhaps more than any other single factor, has come to symbolize the new geopolitics of the twenty-first century. At one level its prominence signals a profound change from the traditional reliance on military and political power. Yet at the same time it is no less an instrument of competition than nuclear weapons or large armies were during the Cold War. The means of international influence today are more diverse and sophisticated, but many of the goals remain as 'old-fashioned' as ever: national security, the projection of power, control over space, and the pursuit of strategic superiority or parity (Lo 2008: 132).

Indeed, it is the stalled energy co-operation between Russia and China where Russia's ambivalence about China's rise and China's concerns about Russia's fickle international behavior clearly manifest themselves (Downs 2010: 165).
\end{abstract}

Since the downfall of the SU more than twenty years ago, energy has come to dominate the foreign policy agenda in both capitals. While Moscow is employing its role as a major energy supplier to wield influence, Běijīng is very much focused on increasing energy security (i.e. security of supply) (Wesner and Braun 2006: 1). A multitude of bilateral energy projects have been discussed since the early 1990s. Progress has, however, been slow and halting, as the two nations found it difficult to be of the same mind at the same point in time (Eder 2014: 36-58).

In the delineation of phases, Erica S. Downs (2010: 146-148) and Yáng Wénlán 杨文兰 (2010: 10) will mainly be followed. They describe a phase of Russianproposed plans in the 1990s that were spurned by a Chinese government able to secure much cheaper supplies on the global spot market. In the 2000s it was the Chinese who were motivated to realise projects in order to diversify their energy sources (away from the Middle East) and prioritise overland routes not controlled by the US Navy. The Russian government, however, kept negotiating in order to maximise prices. Lo (2008: 133) already pointed out the 'imperfect complementar- 
ity' between a country striving for 'security of demand' and a country seeking 'security of supply'.

Nonetheless, a third phase brought major breakthroughs for the Chinese (side) since the onset of the financial crisis in 2008. In short, the Russian side has been losing leverage for years due to severe investment shortages in energy companies, huge deficits, and shrinking foreign currency reserves (Burghart 2010: 91-92, 94; Liú 2010: 30, 35; Yáng Wénlán 2010: 10). The PRC has been happy to provide major loans and investments to both the Russian state and Russian energy companies, who thus became ever more indebted to China (Burghart 2010: 94; Liú 2010: 35-36). As a result, the realisation of energy co-operation projects picked up speed.

Until 1993 the PRC had been self-sufficient in its hydrocarbon supply, only then it became a net importer - first of oil products and then in 1996 of crude oil (Downs 2010: 148; Kozyrev 2008: 202). This was inter alia due to the - still on-going, though reduced - dominance of coal in the Chinese energy mix, i.e. 70-80 percent of energy consumption (Andrews-Speed and Vinogradov 2000: 384-385; Marciacq 2009: 125). Small amounts of oil were imported from Southeast Asia (AndrewsSpeed and Vinogradov 2000: 384-389). Russia, at that time, faced declining levels of oil and gas production (Downs 2010: 150) and could not compete with low prices on the global market (Pomfret 2010: 1). Moreover, China did not have a nuclear sector and thus was not in need of imports of uranium, equipment, or know-how, and there was no infrastructure in place for electricity imports to China (Marciacq 2009: 126; Yáng Wénlán 2010: 13). This is all to say that except for minor oil imports there was no energy co-operation between Moscow and Běijīng, neither in hydrocarbons, nor in nuclear, hydropower, or electricity transfers in general.

In spite of these circumstances, the Russian government saw the enormous potential for a new energy market to the East and proposed major projects. The two main ideas in the hydrocarbon field were an oil pipeline from Eastern Siberia to Manchuria and a gas pipeline linking up to the Kovykta gas field (see Figure 1) (Lo 2008: 144; Marciacq 2009: 130). The former project was later dubbed the Eastern Siberia Pacific Ocean (ESPO) pipeline and was pushed by Mikhail Khodorkovsky's (b. 1963) Yukos Oil Company. The never-ending saga around the ESPO pipeline involved setbacks inter alia due to (1) the dismantling of Yukos (starting in 2003); (2) an alternative Russian plan to build the pipeline to the Pacific coast and export to Japan instead of China - Japan withdrew in 2005; and (3) endless price negotiations (Downs 2010: 157; Jiàn 2009: 2; Kozyrev 2008: 219; Yáng Wénlán 2010: 10; Ziegler 2008: 142). It was only the PRC's overwhelming short-term financial largesse in the economic crisis of the last few years that led to progress (Burghart 2010: 94; Yáng Wénlán 2010: 11). The involved Russian companies Rosneft and Transneft received enormous infusions of 15 billion (bn) US dollars (USD) and ten bn USD respectively from the Chinese side, and suddenly the pipeline from Taishet via 
Skovorodino to Dàqìng 大庆 was built. It went online in 2011 (Downs 2010: 147, 157; Helmer 2011; Yáng Wénlán 2010: 11).

With regard to the Kovykta gas field, however, price disputes continued to hinder any progress, ${ }^{1}$ even after the private owner of TNK-BP (Tyumenskiy Neftyanaya Kompaniya-British Petroleum) - a company that was not allowed to export gas, since Gazprom had the monopoly (Downs 2010: 152-153) — had sold the field to Gazprom (Downs 2010: 156; Kozyrev 2008: 230; Ziegler 2009: 139). ${ }^{2}$

Figure 1 ESPO oil pipeline and Kovykta gas field

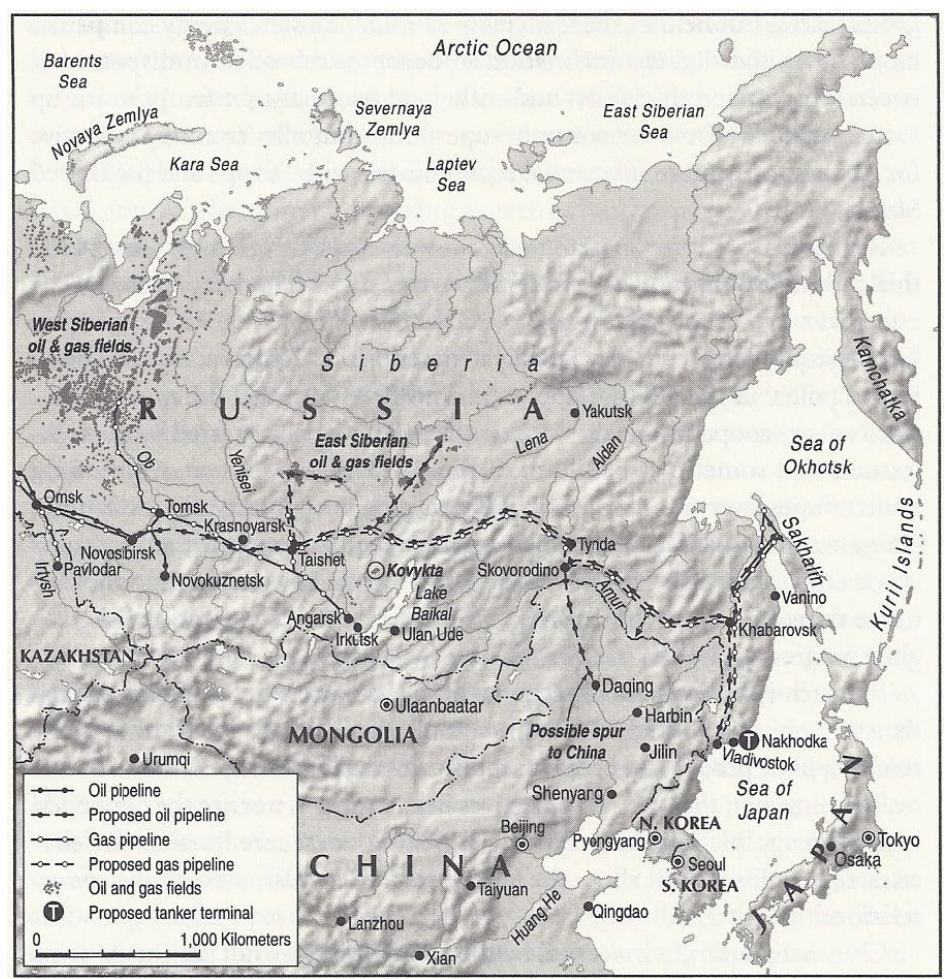

Source: Lo 2008: 142

The nuclear field saw the first success in post-Soviet Sino-Russian energy cooperation. The Russian company Atomstroyexport (ASE) agreed to construct a

1 Cf. Eder 2014: 48, n. 40 where I explain that while Gazprom wants to-as it does with Europe-tie the price to a basket of oil prices, the PRC seeks a price not significantly higher than the price of Chinese coal.

2 On May 21, 2014, the chairmen of Gazprom and CNPC eventually signed a 30-year contract for Russia to provide the PRC with $38 \mathrm{bcm}$ pipeline gas annually from Eastern Siberian fields. Construction of a pipeline shall begin this year, first deliveries are slated for 2018 and full capacity shall be reached in 2020 . The exact pricing formula agreed upon by the parties is not known. 
uranium enrichment plant and a nuclear power plant in Jiāngsū 江苏 province, PRC. Plans for the Tiánwān 田湾 nuclear power station were finalised in 1997, construction began in 1999, and the two reactor units went online in 2006 and 2007 respectively (Wilson 2004: 67, 78-79; World Nuclear Association 2013d, 2013e). In 2010, Jiāngsū Nuclear Power Corporation (Jiāngsū hédiàn yǒuxiàn gōngsī 江苏核电有限 公司) and ASE concluded a deal on a third and fourth reactor unit at Tiánwān, and construction began in 2012 and 2013 respectively - the new units are slated to go online in 2018 (World Nuclear News 2013). This time the Russian side only provided the design and a third of the plants and equipment. The PRC has long ago begun to import uranium from Russia as well (World Nuclear Association 2013d).

In hydropower, the Kremlin was very much taken aback when Russian companies failed to win contracts for the Three Gorges Dam (Sānxiá dàbà 三峡大坝) (Wilson 2004: 76-77). For its Hēilóngjiāng 黑龙江 province however, China started importing minor amounts of hydroelectricity from the RF in 2004 (Overland and Braekhus 2009: 208) and intends to increase these amounts in coming years (Sūn 2010: 2-3).

\section{Chinese and Russian energy projects in Central Asia}

All hydrocarbon projects in connection with CA have to be understood in the context of the Soviet decision to primarily develop fields in western Siberia and the Caucasus and generally construct pipelines east to west towards the principal customer: Europe (Burghart 2010: 83). The result was (1) a state of underdevelopment in CA production and transportation infrastructure; and (2) an export network that provided Moscow with a monopsony, i.e. in the early 1990s all hydrocarbon exports went to or through Russia (Neff 2006: 41-42; Saurbek 2008: 83). China did not even have any trade links with the CA republics at that time, neither in the energy nor in the other sectors (Bosbotinis 2010: 70).

As for existing resources in general, Kazakhstan and Uzbekistan have considerable oil, gas, and uranium reserves, Turkmenistan has enormous gas resources, and Kyrgyzstan and Tajikistan have major hydropower potential (Bosbotinis 2010: 7172; Kassenova 2010: 222; Pomfret 2010: 1; Schmitz 2008: 20).

In the oil sector, Moscow's major successes were the opening of the Caspian Pipeline Consortium (CPC) pipeline from the Tengiz field in Kazakhstan to Novorossiysk in 2001 (Pomfret 2010: 8), and Lukoil's increasing stake in Uzbek oil production - though mainly in co-operation with other foreign companies (including China National Petroleum Corporation [CNPC] [Zhōngguó shíyóu tiānránqì jítuán gōngsī 中国石油天然气集团公司]) and Uzbekneftegaz (Apelt 2008: 14; Buszynski 2005: 562-563). Several incidents, however, demonstrated the dangers of infrastructure dependence on Russia to CA republics. Transneft (RF) controlled all pipelines 
and Russia was the only export possibility. When Kazakhstan for example wanted to expand the CPC pipeline, Russia used its monopoly position to hike transit fees in a way that Kazakhstan perceived as extortion (Neff 2006: 42).

The PRC only started to venture into the CA energy sector in the late 1990s, due to (1) skyrocketing domestic demand; (2) the intention to secure long-term, stable, overland (i.e. pipeline-carried) supply; (3) troubled energy relations with Russia (see preceding sub-chapter); and (4) ameliorating overall relations with CA countries (Herberg 2009: 292; Marciacq 2009: 129, n. 335; Sethuraman and Bierman 2011; Sheives 2006: 210-212). The two key Chinese projects in CA hydrocarbon transport infrastructure were the Kazakhstan-China oil pipeline (see Figure 2) and the CAChina gas pipeline (see Figure 3).

CNPC and KazMunayGas agreed upon the former in 1997, marking the starting point of Běijīng's engagement in the CA energy sector. The Kremlin's manoeuvring regarding the ESPO pipeline contributed to the finalisation of the project in 2005, which in turn increased leverage vis-à-vis Russia (Kozyrev 2008: 216; Sheives 2006: 215). The Kazakhstan-China oil pipeline was eventually filled with both Kazakh and Russian oil in order to bind sceptical Moscow into the project, going online in 2006 (Kozyrev 2008: 216). By 2009, it had been extended to link up the fields around Aktobe next to the Caspian Sea and refineries around Ürümqi (Wūlǔmùqí 乌鲁木齐) in Xīnjiāng 新疆 province, and its volume had doubled (Dorian, Wigdortz, and Gladney 1997: 467; Kozyrev 2008: 216; Marciacq 2009: 130; Pirani 2011: 172).

In addition to the pipeline, CNPC steadily increased its stake in Kazakh oil fields and production and formed joint ventures (JVs) with KazMunayGas (Saurbek 2008: 81; Sheives 2006: 215; Ziegler 2008: 146). The biggest purchase was the Canadianowned PetroKazakhstan - CNPC had outbid Lukoil (RF) - in 2005, which included 11 oil fields, seven exploration blocks, and various assets (Dittmer 2007: 15; Kozyrev 2008: 223). The economic crisis of 2008 did not only change leverage between the PRC and Russia, but also between the PRC and CA governments. The willingness and ability to provide enormous loans and investments helped Běijīng to overcome earlier reservations (Pirani 2011: 173). After 13 bn USD in loans and credits in 2009, Chinese national oil companies were able to gain control over about a fifth of Kazakh oil production. CNPC became a favourite partner of KazMunayGas for Astana's consolidation and nationalisation efforts. The Kazakh government sought to regain control over the partially privatised sector, and China provided part of the necessary funds (Pirani 2011: 172; Pomfret 2010: 9). 
Figure 2 Kazakhstan-China oil pipeline

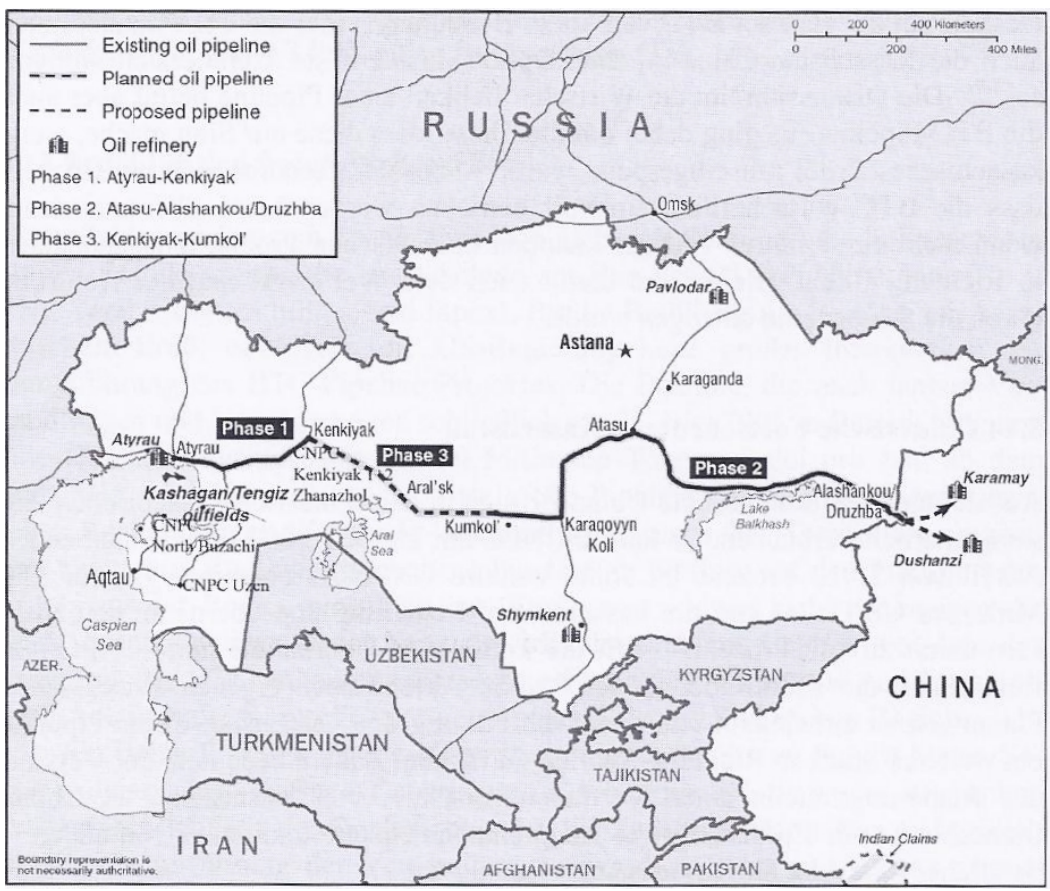

Source: Adolf 2011: 356, citing EIA, "Kazakhstan: Proposed Pipeline to China," EIA Online (2004)

Regarding natural gas in CA, a second (series of) incidence(s) driving CA producers away from Moscow has to be discussed. The Central Asia-Centre pipeline system connects CA to Russia. In the 2000s, Gazprom secured major deals to increase gas infeed from all Turkmenistan, Uzbekistan, and Kazakhstan, and to build an additional pipeline along the Caspian coast (Apelt 2008: 13; Blank 2007: 118; Ziegler 2008: 155-156). In price disputes Gazprom, however, repeatedly refused to buy (or allow the transit of) Turkmen gas as foreseen and repeatedly caused a serious contraction of the Turkmen economy (Anceschi 2010: 100-101; Neff 2006: 41-42). As a result, the Caspian coast pipeline project was not realised, gas import levels from CA (i.e. Turkmenistan) to the RF did not rise as envisioned, and one of the roots of Gazprom's downfall in CA and the rise of CNPC can thus be pinpointed in the Russian side's overly aggressive negotiating style.

The second key Chinese project is the CA-China gas pipeline, which involves mainly Turkmen but also Uzbek and Kazakh exports (Hé and Lǐ 2010: 131). Especially Turkmenistan's fields received enormous Chinese investments (Pirani 2011: 173). Turkmenistan's motivation, as explained, was partly to lessen dependence on 
Russia; China's motivation was to gain leverage against Moscow. Běijīng provided financing - inter alia a four bn USD loan for the pipeline part and three bn USD for field development in Turkmenistan - and construction and management has since been carried out by JVs between CNPC and Turkmengas, Uzbekneftegaz, and KazMunayGas respectively (Anceschi 2010: 101-102; Bosbotinis 2010: 71; Downs 2010: 158-159; Pirani 2012: 84; Socor 2012). Although construction on line A and line B of the pipeline had only started in 2007, the former was finished and went online in December 2009 and the latter in October 2010 (Hé and Ľ̌ 2010: 131; Pomfret 2010: 10; Pirani 2012: 84; Socor 2012, August 9). Construction of line C, intended to go online in 2015, has begun as well (Pirani 2012: 84). While the capacity of the pipeline rose gradually by adding compressor stations (ibid.), the agreement was for 30 billion cubic meters per year (bcm/year) (over 30 years) from Turkmenistan and ten bcm/year from Uzbekistan (Socor 2012). Aside from the pipeline, CNPC struck numerous bi- and multilateral deals with Uzbekneftegaz and set up JVs (e.g. AsiaTransGas) (Khodzhaev 2009: 19; Kozyrev 2008: 223-224; Ziegler 2008: 156-157).

Figure 3 CA-Caucasus gas pipeline network

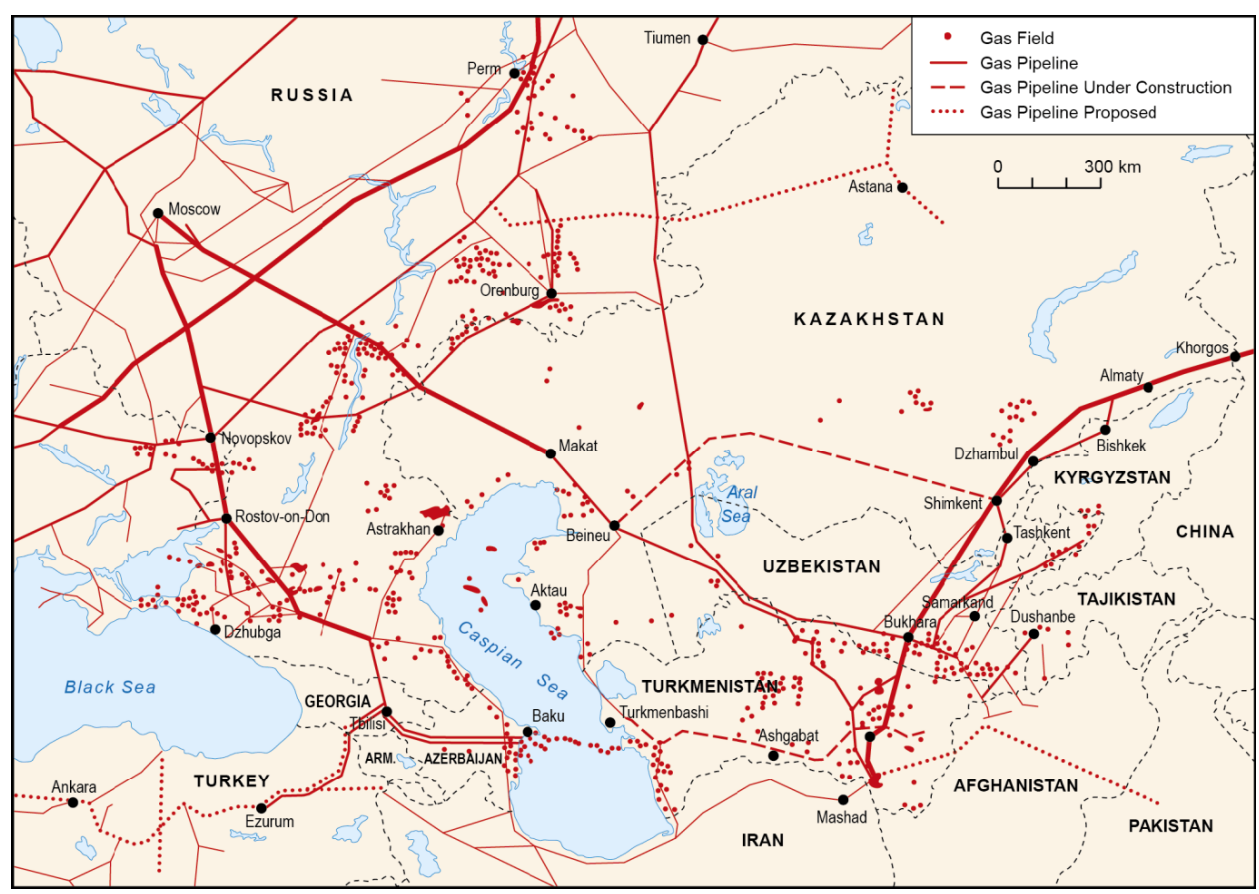

Source: Pirani 2012: 1 
The RF was still the dominant external actor in the CA uranium production and nuclear sector in the 1990s (Marciacq 2009: 126). Kazakhstan had the only operational nuclear power plant in the region until it went offline in 1999 (Kassenova 2010: 232, 240-241). The dominant local companies were Kazatomprom, Navoi Mining and Metallurgy Plant (Uzbekistan), and Kara Balta Ore Mining Company (Kyrgyzstan) - taken over by Renova (RF) in 2007-(Kassenova 2010: 222-229; World Nuclear Association 2013f). Both Russia and China were importing CA uranium at the turn of the century.

Since 2006, Moscow and Astana have established several JVs to explore uranium mines, process Kazakh uranium in Angarsk (RF), and construct a new nuclear reactor in Aktau, Kazakhstan by 2015 (Kassenova 2010: 223-225, 232; Schmitz 2008: 20; World Nuclear Association 2013f). The Kazakh government has, however, also started to conclude strategic co-operation agreements with the China National Nuclear Corporation (CNNC) (Zhōngguó hégōngyè jítuán gōngsī 中国核 工业集团公司) and China Guangdong Nuclear Power Group (CGNPG) (Zhōngguó guăngdōng hédiàn jítuán 中国广东核电集团) in 2006. Kazatomprom set up JVs with them, Kazakhstan became the PRC's central supplier of uranium and nuclear fuel, and CGNPG and Kazatomprom formed a JV for the construction of nuclear power plants in China in 2009 (Bosbotinis 2010: 71-72; World Nuclear Association 2013d, 2013f). An Uzbek-Russian JV set up in 2006 was dissolved in 2010 (World Nuclear Association 2013b), while CGNPG succeeded in setting up UZ-China Uran, a JV, with Uzbekistan's Goskomgeology with the goal of starting production in 2014 (Kassenova 2010: 230-232; World Nuclear Association 2013b). Chinese (including Hong Kong) companies also made forays into Turkmenistan, Tajikistan, and Kyrgyzstan, but no definite progress was achieved (Kassenova 2010: 227; Pomfret 2010: 10).

In the field of hydropower, the Unified Energy System of Russia (RAO-UES) has reconnected Russian and CA electricity networks since 2000, and the RF started to import Kyrgyz and Kazakh hydroelectricity again. RAO-UES also runs SangtudaI and Rogun-I hydroelectric stations in Tajikistan together with Barki Tojik (TJ). Rogun-II should have been run by RusAl (RF), but the company withdrew from the project (Peyrouse 2007: 134, 140-141). Běijīng achieved first electricity linkages with CA in the late 1990s (ibid.: 145), when Astana agreed to jointly construct a hydroelectric station in Khorgos on the border, and China agreed to provide financing for another one in Moinak, Kazakhstan (ibid.: 138-139). In Tajikistan, Sinohydro was awarded a hydropower project in Penjikent in 2005, and China will, together with Barki Tojik, finance and carry out the connection of northern and southern Tajikistan grids, allowing for exports to Kyrgyzstan and Afghanistan (Ibraimov 2009: 51; Peyrouse 2007: 142-143). Moreover, the PRC agreed to finance multiple hydropower stations in Kyrgyzstan and expects significant exports to Xīnjiāng province (Peyrouse 2007: 144-146). 


\section{Changing views on the 'CA factor': The Chinese discourse and its development}

The earlier study mentioned above determined that a neoclassical realist-perception theory approach had substantial explanatory power regarding the research question of how shifts in the CA energy sector impact Sino-Russian relations. Neoclassical realism holds that systemic pressures provide governments with policy choices, that domestic variables lead to the eventual choice among them, and that one such variable is perception of the issue by influential groups. Among such groups are the 'proximate elite' (i.e. the government) and different 'influential elites' (i.e. those who influence the decisions of the government). Among the 'influential elites' one can inter alia find foreign policy/IR experts, who are part of strategic assessment and strategy formulation processes. Said study thus strove to provide a broad and thorough picture of Chinese foreign policy/IR experts' views as expressed in Chinese language journals published in mainland China. With this in mind, 120 articles from 40 journals, written by 82 experts of three different generations and produced over a 15-year span from 1997 to 2012, were analysed.

The results have shown significant changes in the debate over three distinct phases (cf. Eder 2014: 98-131; cf. also Liǔ 2007: 63-64): (1) 1997 to 2001, when the issue was not discussed; (2) 2001 to 2008, when China was singled out to be the Kremlin's ideal partner in rebuffing Washington's advances; and (3) 2008 to 2012, when Chinese and Russian interests were increasingly seen at odds, while experts called for compromise and blamed Russia at the same time.

\section{Phase one: No comment}

The first phase is set from the agreement on the first major Chinese project involving CA energy resources, the Kazakhstan-China oil pipeline, in 1997 to the beginning of the Afghanistan War in 2001. Then, neither energy nor the CA region featured prominently in Chinese authors' discussions on intensified co-operation with Russia. If energy co-operation (e.g. Qi 1998) or CA (e.g. Féng 1997) were mentioned as a factor in the Sino-Russian relationship, it was mainly as positive drivers. However, some authors noted that Moscow did not want CA states to gain 'more sovereignty' through achieving energy independence (Shí 1998: 2) and that excessive transit fees 'harm the interests of Central Asian countries and endanger Central Asia's economic safety' (Yú 2000: 35). ${ }^{3}$ Běijīng's intentions were only hinted at by

3 'Zhè bùjĭn gěi Zhōngyà guójiā zàochéng le yănzhòng de lìyì sǔnshī érqiě hái wēihài dào tāmen de jīngjì ānquán' 这不仅给中亚国家造成了严重的利益损失而且还危害到它们的经济安全 (This not only greatly harms Central Asian countries' interests, but also endangers their economic security). 
stating that CA needed a regional energy market and more foreign capital (Fán, Yú, and Ľ̀ 2000: 2-3).

\section{Phase two: Helping hand}

The second phase begins with the US invasion of Afghanistan and ends with the onset of the financial and economic crisis in 2008. It did not bring a more substantial discussion of CA in articles on Sino-Russian relations, be they on energy or other issues. With energy, the focus was clearly on bilateral projects, i.e. the ESPO pipeline, the Kovykta gas field, and nuclear co-operation (e.g. Zhōu 2006). The overall tenor on energy co-operation remained very positive (e.g. Diāo 2005a, 2005b; Yáng 2007). Problems are mainly ascribed to other actors, i.e. the US and Japan (e.g. Hán 2006: 4-5). Russian fears regarding China are discussed, but immediately discarded, claiming that they are due to the 'China threat theory's' prevalence (e.g. Lǐ 2005: 5), 'Cold War thinking' (lěngzhàn sīwéi 冷战思维) and 'extreme nationalism' combined with a failure to comprehend Běijīng's 'peaceful development' and 'neighbourly diplomacy' (cf. Liǔ 2007: 63). It was mentioned, though, that Běijīng's CA policy had to be emancipated from considerations regarding Moscow (e.g. Liǔ 2007: 69), ${ }^{4}$ which is said to have happened around 2001 - as could be seen, among others, from the establishment of the SCO. Authors also noted that the RF constantly tried to block projects by other external actors (e.g. Sūn 2004: 19).

The main thrust of the discourse at the time was 'US-Russia relations' turning from co-operation to competition' (méi'è guānxī yóu hézuò zhuănxiàng jìngzhēng 美 俄关系由合作转向竞争) (Shí 2005: 37). Washington's intrusion into former Soviet/Russian space was described in terms of its military dimension-i.e. establishing military bases for the Afghanistan War (e.g. Liú 2006: 18); in terms of its political dimension-i.e. democratisation efforts ('colour revolutions') in former Soviet republics like Kyrgyzstan (e.g. Liǔ 2007: 71-72); and in terms of its economic dimension-i.e. energy projects (e.g. Shí 2005: 38-39). Against this intruding competitor-alleged to have broken up the Russian monopoly on CA exports, which is only true if the Caucasus is included - and against its 'unilateralism' (dānbiān zhùyi 单边主义) and 'hegemonism' (bàquán zhùyì 霸权主义) (e.g. Shí 2007: 49) and the 'Westernisation' (xîfānghuà 西方化) of CA (e.g. Liǔ 2007: 72), the PRC proposed a joint opposition. Moreover, China should help the Kremlin nationalise the energy sector (Yú Yáng 2007: 35) and invest more in it itself (Hán 2006: 7), involve Russia

4 'Zhōngguó yú zhōngyà guójiā de guānxī zhuàngkuàng bùjǐn qǔjué yú shuāngfāng de lìyì hé jiāowăng, érqiě zài xiāngdāng dà de chéngdù shàng shòudào éluósī yīnsù de yìngxiàng' 中国与中亚国家的关系状况不仅 取决于双方的利益和交往, 而且在相当大的程度上受到俄罗斯因素的影响（The condition of China's relations with Central Asian countries did not only hinge on mutual interests and contacts, but to a quite considerable extent was influenced by the Russia factor). 
in Chinese projects in CA (Xú, Chéng, and Wáng 2007: 58), invest generously in the Russian Far East and Eastern Siberia (Hăo and Wáng 2006: 8), and use the SCO for energy co-operation (e.g. Wáng 2006: 21; Xià 2007: 8).

\section{Phase three: Inevitable advance and co-operative embrace}

The third and last phase begins with the 2008 economic crisis, which had an impact on all involved actors, and ends in 2012. This can be considered the most important period of study, because Chinese involvement in the CA energy sector reached a completely new level, as Běijīng made effective use of its increased leverage due to the other actors' massive financial constraints (e.g. Liú 2010: 35-36; Sūn 2010: 1). Discussion of the issue of CA energy resources for Sino-Russian relations became much more prominent - as did the issues of CA and energy separately.

Sino-Russian energy co-operation was still presented in a positive light (e.g. Chén Xiànliáng 2010; Jiàn 2009; Xú and Wáng 2009). Reasons for not having achieved even more are seen on both sides, though mainly the Russian one. The PRC is deemed to have missed opportunities in the late 1990s and to have had a late start against international oil companies, while suffering from lacking expertise, experience, internalisation, and effective administration in Chinese national oil companies (Xú and Wáng 2009: 19-20). The RF is said to have production problems (e.g. Wáng 2011: 7-8), a bad investment climate (e.g. Pān 2011: 66), and to be impossible to conclude price negotiations and carry out major pipeline projects with (e.g. Jiàn 2009: 2; Yáng Wénlán 2010: 12). Moreover, Moscow is claimed to still focus its attention on its customers to the west (e.g. Wáng 2011: 7; Wú 2011: 13), and its behaviour towards dependent Ukraine is held up as a cautionary tale (Yáng Wénlán 2010: 2; Zhōu and Wáng 2009: 9). Finally, it is once more the 'China threat theory'-leading to fears of a 'raw material dependency' (yuánliào fùyōng 原料附 庸) (Sūn 2010: 3) or a 'resource colony' (néngyuán zhímíndì 能源殖民地) (Wú 2011: 13) and fears of resources being 'plundered' (lüèduō 掠夺) (Chén Xiànliáng 2010: 27) — that is said to negatively influence the Russian discourse and thus hinder stronger co-operation.

A positive outlook was also maintained on the PRC's energy relations with CA. Successes are said to be 'natural' due to the 'good neighbourliness' policy (cf. e.g. Zhào 2010a: 65) and CA is said to be crucial for Chinese energy security (e.g. Zhāng Yào 2009: 116). This role of CA is ascribed to (1) Běijīng's need for import diversification (e.g. Qián 2011: 86); (2) the geopolitical importance of energy ties with CA 
(e.g. Zhāng Yào 2009: 116); ${ }^{5}$ (3) the inherent necessity to develop economic ties as part of the 'good neighbourliness' policy, which is 'inevitable' (cf. Zhào 2010: 38); (4) CA being more stable than the Middle East (e.g. Qián 2011: 86); (5) CA allowing for overland transport (e.g. Zhāng Yào 2009: 126); (6) CA energy resources (see Table 1) being allegedly cheap (e.g. Wáng 2008: 44); (7) CA possibly allowing for overland transport of both Russian and Middle Eastern energy resources (e.g. Chén 2011: 90; Láng and Wáng 2008: 1781-1782); (8) domestic resources (see Table 1) being allegedly more expensive to extract and their importance as a strategic reserve (e.g. Wáng 2008: 44); and finally (9) the role of Sino-CA co-operation in stabilising and developing both Xīnjiāng and the PRC's neighbours to the west (e.g. Wáng 2008: 44; Zhāng Yào 2009: 128). This all leads Wáng Xiăoméi (2008: 43) to posit that 'strengthening energy co-operation with Central Asia is an inevitable choice in Chinese energy strategy'.

Among other Chinese authors, Zhào Míngwén, who expects Sino-CA relations to become 'even more inseparably linked' (gèngjiā jǐnmi xiānglián 更加紧密相连) (2010a: 65), touts the PRC's advantages over other major powers. According to him, since the financial crisis, no other country (including Russia) is committing itself to major regional investments comparable to those of the PRC (ibid. 2010b: 8).

At this point, PRC IR experts begin to more expressly and thoroughly discuss the impact of the new Chinese presence in the CA energy sector on the relationship with Moscow. They acknowledge (1) that Russia's position has been challenged by the PRC (e.g. Wú 2009: 33; Zhào Huáshēng 2011: 21-22); (2) that its monopoly regarding Kazakh and Turkmen exports has been broken up by the PRC, leading to disadvantages for the Kremlin in negotiations (Chén 2011: 91); (3) that it is Sino-CA energy relations that have been growing the fastest (e.g. Fāng 2008: 4; Hú 2010: 4-6; Zhào 2010b: 7); (4) that further Chinese successes, which are going to happen, will further weaken Russia in CA (Zhào 2010c: 66); (5) that Moscow's reunification efforts might be harmed due to China (Zhào Huáshēng 2011: 21-22); and (6) that a 'huge political crisis' might ensue (Zhào 2010c: 66). Competition is said to be unavoidable (Chén 2011: 89) and even expected to be 'fierce' and 'protracted', as neither side can simply retreat (Zhào 2008: 6).

Authors note Russian concerns over growing Chinese influence (e.g. Pān 2011: 66; Wáng 2009: 4; Zhào Huáshēng 2011: 20-21)—the aforementioned Zhào Míng-

5 'Cóng chángqĩ láikàn, zhè zhǒng hézuò bìngbù jǐnjǐn shì zhōngguó yú zhōngyà zhījiān jīngjì hùlì de xǔyào, gèngyǒu dìyán zhèngzhì liỳ̀ shàng de kăoliang hé xǔyào' 从长期来看, 这种合作并不仅仅是中国与中亚 之间经济互利的需要, 更有地缘政治利益上的考量和需要, 对于未来中国的能源安全有着十分重要的 意义 (From a long-term perspective, this kind of co-operation is not only a necessity of mutual economic benefits between China and Central Asia, it is, moreover, a necessity on the basis of geopolitical benefits, having enormous significance for China's future energy security).

6 '[...] Jiāqiáng yú zhōngyà de néngyuán hézuò shì zhōngguó néngyuán zhànlüè de bìrán xuănzé’ 加强与中 亚的能源合作是中国能源战略的必然选择. 
wén even registering 'continuous complaints' (2011: 40) — and attempts to replace Sino-CA projects with newly proposed Sino-Russian ones (ibid. 2010c: 66). Russian sources are quoted as now seeing the PRC as the 'principal competitor' (cf. ibid. 2010b: 7), a 'geopolitical opponent' (cf. Xú and Wáng 2009: 18), and an upcoming replacement in the region (e.g. Fāng 2008: 4; Zhāng Yè 2009: 15-16), draining off energy resources to the East (Fù 2009: 46) ${ }^{7}$ and only waiting to turn economic influence into political influence (Zhào 2010b: 6-7). ${ }^{8}$

The RF's responses are claimed to involve reinforcing regional integration efforts without Chinese participation (e.g. the Collective Security Treaty Organization [CSTO], the Eurasian Economic Community [EurAsEC], a tariffs union, and the Eurasian Union) (e.g. Zhāng Yè 2009: 16). Moreover, funds for SCO projects are allegedly withheld (e.g. Zhào Huáshēng 2011: 21), and vain attempts to outdo Chinese spending allegedly undertaken (e.g. Zhāng Yè 2009: 16).

According to Chinese scholars, these responses from and fears on the Russian side are to blame for friction (e.g. Zhào 2010: 38), ${ }^{9}$ as is the RF's continued 'sphere of influence thinking' (shili fànwéi sīwéi 势力范围思维), which is said not to be in line with today's world (Wáng 2009: 8). Parallels are drawn to Moscow's mounting issues with former Soviet Republics in Eastern Europe and the EU in regard to possibilities for similar friction between Russia and China in CA (Wáng 2009: 8). ${ }^{10}$

Yet, fears are judged as unfounded, as the PRC is said to only want a stable neighbourhood (e.g. Hé and Lǐ 2010: 131). Moreover, the PRC supposedly under-

7 'Zhōngguó zài Zhōngyà dōngbù dìqu xíngchéng gèngjiā zhijiē biànjié de néngyuán guăndào wăngluò, shǐ zhōngyà yóuqì zīyuán zài xīxiàng hé dōngxiàng liăngge fāngxiàng liúshī, ér běixiàng de Xībólìyà guănxiàn wăngluò suǒzhàn de fêné jiāng yuèláiyuè shăo’ 中国在中亚东部地区形成更加直接便捷的能源管道网络, 使中亚油气资源在西向和东向两个方向流失, 而北向的西伯利亚管线网络所占的份额将越来越少. (China establishes an even more direct and convenient pipeline network in Central Asia's eastern part, leading Central Asia's oil and gas resources to be drained off to the east and west [this implies the crossCaspian pipeline projects to Europe], the share of the northwards Siberian pipeline-network will be less and less).

8 'Zhōngguó yú Zhōngyà guójiā jīngji hézuò de fāzhăn wéilái kěnéng dăozhì dìfāng jīngyíngzhe gǎibiàn zhèngzhì hé ānquán qǔxiàng cóng Éluósī zhuănxiàng Zhōngguó' 中国与中亚国家经济合作的发展未来可 能导致地方经营者改变政治和安全取向从俄罗斯转向中国 (The future development of Sino-Central Asian economic co-operation might lead to the local elites changing their political and security orientation from Russia to China).

9 'Zhèlì wèntí de zhèngjié bùzàiyú Zhōngguó duì Éluósī de tàidù, ér zàiyú éluósī duì zhōngguó de fănyìng, yīnwéi shì zhōngguó jìnrùle yuánshǔ Éluósī de kòngjiān' 这里问题的症结不在于中国对俄罗斯的态度, 而在于俄罗斯对中国的反应, 因为是中国进入了原属俄罗斯的空间 (The crux of this problem does not lie in China's attitude towards Russia, but in Russia's response to China, because China has entered a region that used to belong to the Russian sphere).

10 'Éluósī huĩfù shilì fànwéi de nǔlì, zhèngzài wàigāojiāsuǒ hé Zhōngyà yǐnfā yú dìqū guójiā jí Méi, Ōu yùláiyùduō de chōngtū, cúnzài dăozhì Zhōng-É zài Zhōngyà fāshēng mócā de wēixiănxìng’ 俄罗斯恢复势 力范围的努力, 正在外高加索和中亚引发与地区国家及美、欧愈来愈多的冲突, 存在导致中俄在中亚 发生摩擦的危险性 (Russia's efforts to recover a sphere of influence currently lead to more and more conflicts with regional countries, the US and the EU, the danger exists that this could [also] lead to SinoRussian friction in Central Asia). 
stands Russia's feelings regarding former Soviet territory (e.g. Zhào 2010: 40), and it is said that the PRC will not diminish Russian interests in CA (e.g. Hé and Ľ 2010: 131) (cf. however Table 2), and that it supports the RF in the priority issue of countering the West (Hé, Amuti, and Zhāng 2008: 43).

Regarding the potential for friction, Chinese scholars are under no illusions, as 'to ignore or deny this would be neither objective nor wise' (hüshì hé fòurén zhè yìdiăn shì bù kèguān hé bù míngzhì de 忽视和否认这一点是不客观和不明智的) (Zhào 2010: 41). Aware of Western studies that expect imminent confrontation, Chinese authors both downplay differences in interest and sketch out countermeasures and co-operation policies that shall overcome them. According to Zhào Huáshēng (2010: 42), Sino-Russian relations are more equal than one might think, due to a generally resurgent RF with deep regional roots. He does not expect containment efforts. Though he acknowledges that the US presence adds motivation, he says the partnership, which is older than $9 / 11$, will not be harmed by the scheduled US withdrawal in 2014. Common interests and a growing co-operation potential are expected to overcome all outstanding issues (e.g. Chén 2011: 90; Wáng 2009: 9; Zhào 2008: 6-7; Zhào 2010: 41-42). Among common goals are (1) a stable and secure CA; (2) economic development in CA; (3) countering Western influence; (4) fighting terrorism; and (5) fighting drug trade (e.g. Chén 2011: 92).

Scholars develop a host of recommendations to smooth over misgivings and friction. First of all, understanding and patience are called for as the 'former superpower' Russia feels 'geopolitical pressure' (Shǐ 2011: 50) and still has to come to terms with China's rise (Fāng 2008: 4). In that vein, Moscow should be included in the PRC's deliberations, constantly reassured, and provided with generous investments (Hé and Lǐ 2010: 131; Wáng 2011: 8). Moreover, Běijīng should work with Russian authorities on migration issues, make clear that there will never be territorial claims, and push bilateral energy projects - coordinated by newly configured, specialised 'small-groups' (xiăozú 小组) (Wáng 2011: 8-9). Furthermore, many authors strongly emphasise the need to make use of the SCO framework to coordinate the two nations' energy interests (e.g. Chén 2011: 89, 93; Fāng 2008: 4; Féng 2008: 66; Wáng 2009: 4), develop standard practices (Zhào 2010: 38), and pool Russian and CA export potentials (Pān 2011: 66). Within the SCO, the RF could monitor and influence Chinese activities in CA (Zhào Huáshēng 2011: 20). Even an SCO energy club, which possibly could learn from the European Energy Charter, is touted (Féng 2008: 66).

For the moment, the Chinese discourse of this period described CA as under no 'definitive geopolitical jurisdiction' (quèdìng de dìyuán zhèngzhì guīshŭ 确定的地 缘政治归属) (Zhào 2008: 5), with Russia and China both being hard to ignore (Wáng 2009: 4), and with regard to CA energy resources there is said to be no 
'permanent winner' (Fāng 2008: 3). ${ }^{11}$ Nonetheless, Russia supposedly already suffered and conceded 'strategic defeats' (zhànlüè shībài 战略失败) (Zhào 2010a: 64, 2010b: 7) against China, by losing the monopoly on gas exports from CA and by being clearly outdone as an economic partner for Tajikistan. Moreover, some authors consider a US withdrawal from Afghanistan to likely lead to even more Chinese influence, which could in turn exacerbate Sino-Russian tension (Yáng Léi 2010: 37).

\section{New energy projects: Playing chess in the Eurasian Steppe. Confirm- ing the Chinese discourse}

Central Asia is the thickest piece of cake given to the modern Chinese by the heavens ${ }^{12}$ (General Liu Yazhou of China's People's Liberation Army).

The Chinese discourse and predictions laid out in the preceding chapter shall now be reviewed against the backdrop of events in the last one and a half years as well as against recent Western literature on the subject.

Interestingly for the developments in the energy sphere, Alexandros Petersen makes the argument that it is mainly forces outside the Chinese government and party leadership that push the expansion of Chinese influence in CA (2013a). According to him, (1) the foreign ministry does not prioritise the region in any way, certainly does not send top diplomats there, and does not even have a Kazakhstan desk; and (2) the Politburo and the People's Liberation Army (PLA) see CA only as indirectly important, with the hope that it is a calm and prosperous neighbourhood for the province of Xīnjiāng. State-owned enterprises (SOEs) and especially the national oil companies, however, push for a stronger regional involvement because they see an opening against weak competitors with 'less financial power, more strings attached, more misgivings about practices' regarding a directly adjacent rich resource base and potential market (ibid.).

According to Georgiy Voloshin, however, a real strategy is in the works from the government side as well (2013b). This is said to have been 'unveiled [by Xí Jìníng 习近平 (b. 1953) on 7 September 2013, in the form of] Beijing's proposal to establish a new regional framework undergirding the so-called Great Silk Road diplomacy' (ibid.). Jacob Zenn elaborates that the Chinese 'Silk Road economic belt' concept is meant to mainly counter the US 'new Silk Road' strategy, and adds that it is Běijīng who has got the odds in its favour (2013). The Chinese concept was

11 'Kěyǐ kěndìng de shì zhōngyà néngyuán de lùxiàntú bù huì yǒu yǒngyuăn de yíngjiā [...]' 可以肯定的是中 亚能源的路线图不会有永远的赢家 [...] (What is certain, is that the 'route-map' of CA energy will not have a permanent winner $[\ldots])$.

12 Petersen 2013a. 
presented in a speech in Uzbekistan's historical Silk Road centre of Samarkand. In the speech, Xí sought a personal connection when talking about his roots in Shănxī 陕西 province, the capital of which is Xī’ān 西安, the old Cháng'ān 长安 that served as the eastern end of the Silk Road (ibid.).

The SCO summit in Bishkek on 13 September 2013 is already being described as the 'coming out party' of the PRC as the new economically dominant power in CA, whereas Zenn argues that this trend was kept under wraps until 'Chinese predominance was secured' (ibid.). Furthermore, at least Kazakhstan's elites are claimed to be increasingly turning towards Běijīng (Voloshin 2013b).

As explained in the introductory part of this paper, the PRC only started venturing into the CA energy sector in 1997, when the Kazakhstan-China oil pipeline was agreed upon. In the summer of 2012, it was already a formidable force.

Since then it has become clear that Běijīng has only begun to unfold its plans. Similar to the Russian national oil company giant Gazprom, the Chinese CNPC has adopted a comprehensive strategy, wherein it seeks not only to acquire and transport oil and gas to China, but also to (1) acquire oil and gas fields, production facilities, and local companies; (2) control a regional transport network; and (3) connect the entire region with this network. The latter part means that Kyrgyzstan and Tajikistan - plus maybe Afghanistan - shall become part of the network that so far includes the producers Kazakhstan, Uzbekistan, and Turkmenistan and the consumer China. Moreover, resource-poor parts of said energy exporting nations shall also be connected (Petersen 2013c). According to Petersen, ever more confident representatives of CNPC have already told their Gazprom counterparts 'that Central Asia [is] China's turf when it comes to energy' (2013c, cf. also ibid. 2013b). He focuses in on CNPC in particular, shows how it has surpassed all Western international oil companies in controlling Kazakh oil production, and demonstrates how it has in fact replaced Gazprom as the overall energy hegemon of the region (ibid. 2013c).

Regarding the expansion of the Chinese energy network in CA, its forays into Afghanistan should be taken note of. CNPC has already started oil extraction in Sare-Pul province, negotiates about expanding production, and plans both a refinery inside Afghanistan, and including the north of the country in its gas pipeline network (ibid.).

Talking about the sustainability of the current trend, Petersen points to what has already been done to secure CA gas, and the steadfast commitment to make gas, making up only five percent of the Chinese energy mix at present, a much more important factor in Chinese energy consumption even in the short-term (ibid.). 
Sino-Russian energy co-operation

As for Sino-Russian bilateral energy relations, Petersen explains how the shifting balance of power can be seen in the March 2013 preliminary export agreement between Gazprom and CNPC (2013b; cf. also Brill Olcott 2013). Only after years of negotiating, and making several adjustments to an already favourable price, was an agreement finally signed that does not include a timeline or volumes. ${ }^{13}$ Stephen Blank points to the issue of Russian companies losing all 'leverage vis-à-vis China, as they take on huge amounts of debt from Chinese banks and companies' (2013).

Progress, however, is being made. Also in March 2013, Rosneft and CNPC reached a deal on the delivery of 365 million tons of oil over 25 years for 270 bn USD (including a pre-payment of $60-70$ bn USD). This will be delivered mostly through the ESPO pipeline (ibid.). Rosneft also agreed with KazMunayGas and KazTransOil to significantly increase Russian oil and gas deliveries to China via Kazakhstani infrastructure on 11 November 2013 (Assenova 2013). CNPC secured a 20 percent stake in the independent gas producer Novatek's liquefied natural gas (LNG) project on the Yamal Peninsula in June 2013 (Blank 2013; Brill Olcott 2013). In October 2013, CNPC and Rosneft concluded a Memorandum of Understanding $(\mathrm{MoU})$ regarding a new JV-of which Rosneft will hold 51 percent - to explore a number of oil and gas fields in eastern Siberia. Additionally, Rosneft and Sinopec concluded a fresh deal worth 85 bn USD (Blank 2013).

As for future negotiations, however, the PRC, which only became a net importer of natural gas in 2008 (Rousseau 2013: 43), already produces $76 \mathrm{bcm} /$ year itself and has recently discovered substantial shale gas deposits. This 'will only further strengthen China vis-à-vis Russia and Central Asia on gas issues" ${ }^{14}$ (Kim and Blank 2013: 784-785).

\section{CA hydrocarbons (I): Oil}

Concerning the CA oil sector, Kazakhstan is clearly the most important exporter. Alexander Kim explains that although the PRC is currently the destination of 'only' 12 percent of Kazakh oil compared to the EU's 72 percent, the balance is rapidly changing (2013). Běijīng has gained further access to key Kazakh oil fields (mainly Kashagan), in exchange for 13 bn USD worth of credit lines to the Kazakhstani Welfare Fund, the copper company Kazakhmys, and the Kazakh petrochemical and uranium industry (Kim 2013; Rousseau 2013: 41). Its stake in Kazakh oil production is now 21 percent, which is more than 2.5 times the Russian number (Kim and Blank 2013: 783). The amount of oil exported to China from Kazakhstan that stood

13 See note 2.

14 Emphasis added by author. 
at 12.1 million tons/year in 2011 is expected to rise to about 22 million tons/year by 2020. This will inter alia be achieved by expanding the Kazakhstan-China oil pipeline (Rousseau 2013: 43).

ConocoPhillips originally wanted to sell the 8.33 percent share in the Kashagan field ${ }^{15}$ to the Indian Oil and Natural Gas Corporation Limited (ONGC), however the Kazakh government made use of its right of pre-emption to sell it to CNPC instead (Zenn 2013; cf. also Brill Olcott 2013). The deal was signed on 7 September 2013 and cost the Chinese side five bn USD for their own share and a contribution of three bn USD - or half of Kazakhstan's costs (Voloshin 2013b) - to the Kazakh share (Socor 2013).

The dimension of this becomes obvious in the context of Kashagan being the biggest discovery in the oil world since the Prudhoe field in Alaska in the 1960s. It has 35-38 bn barrels oil in place and 9-13 bn barrels recoverable oil and will at first produce about 75,000 barrels per day (bpd), with targets of 180,000 bpd in 2014 and a full capacity of 1.6 million bpd after 2016. Production has just begun in September 2013 (ibid.). Participating companies can decide to export (1) through the CPC pipeline to Novorossiysk at the Black Sea and onwards via tanker; (2) through the Atyrau-Samara pipeline to or through Russia; (3) through the Atasu-Alashankou pipeline to China; or (4) via tanker to Azerbaijan (ibid.).

Aside from oil production, Chinese companies also invest in refinement inside Kazakhstan, helping the country reduce the share of Kazakh oil being refined in Russia, for example through supporting the construction of a fourth refinery (Voloshin 2013b). Běijīng also secured further contracts in the Uzbek oil sector among the 15 bn USD worth of deals signed in September 2013 (Zenn 2013), and it is planning an oil pipeline from Kazakhstan through Kyrgyzstan to China (Kim and Indeo 2013: 282).

\section{CA hydrocarbons (II): Gas}

Regarding Sino-CA co-operation in the gas field, the inauguration of the BeyneuBozoy-Shymkent gas pipeline from south-western Kazakhstan to Xīnjiāng in September 2013 represents another milestone. The pipeline's capacity will be six bcm/year (Voloshin 2013b; Rousseau 2013: 43). As explained above, extending credit lines to Kazakh institutions has helped the PRC gain access to new oil fields. This holds true for the gas sector as well, where Karachaganak has been the biggest success (Kim 2013).

When it comes to the CA-China gas pipeline, Vladimir Socor notes the agreement on the SCO Summit in Berijīng 2012 to increase the capacity-formerly at 30

15 Kashagan oil field is run by an international consortium (North Caspian Operating Company [NCOC]), which consists of KazMunayGas, Agip, ExxonMobil, Shell, Total, Japanese Inpex, and now CNPC. 
bcm/year - to 65 bcm/year (2012; cf. also Kim and Indeo 2013: 283). This should be achieved by adding compressor power to line A (commissioned December 2009) and line B (commissioned July 2010) and by constructing a line C. The latter was started in 2011 after agreements between CNPC and Uzbekneftegaz and CNPC and KazMunayGas, who are jointly constructing it and then will jointly operate it. It will go online in 2015 and will reach full potential $(25 \mathrm{bcm} /$ year) in 2016 (Pirani 2012: 83; Socor 2012). Another expansion is planned to add ten bcm/year of Kazakh gas in connection with the completion of the Beyneu-Bozoy-Shymkent gas pipeline. However, the two sides have not yet agreed on the details of the project (Pirani 2012: 84). Generally, projects between Astana and Běijīng are slowed down by questions of how to divide resources as well as funding and controlling production and transportation (ibid.: 87).

Simon Pirani explains that of the gas exported through the CA-China gas pipeline up to 2012, one third was from CNPC's production at Bagtyiarlyk, Turkmenistan, and nearly two thirds were from Turkmengaz production at the Malay and Uchadzi group of fields (ibid.: 84). Uzbek contributions were negligible; whereas Uzbek export problems are ascribed to high domestic consumption (ibid.: 88).

Moreover, it was decided to build a branch line from Kazakhstan through southern Kyrgyzstan to China. This should accomplish (1) connecting Kyrgyzstan to the PRC-led gas infrastructure; (2) increasing cohesion between northern and southern Kyrgyzstan; and (3) reducing Kyrgyzstan's dependence on Uzbek gas (Socor 2012; cf. also Kim and Indeo 2013: 282).

On 4 September 2013, production started at the huge Galkynysh (which means 'revival' in Turkmen) gas field (Zenn 2013; cf. also Brill Olcott 2013) -formerly known as South Yolotan and renamed in 2011 (Petersen 2013c). This is the second largest gas field in terms of production in the entire world and there is no comparable operation anywhere without the participation of an international oil company (Brill Olcott 2013). Deals worth 15 bn USD concluded between China and Uzbekistan on 9 September 2013 also included sizeable gas purchases (Zenn 2013). On 11 September — next to concluding a 'strategic partnership' with Kyrgyzstan — China pledged three bn USD for a gas pipeline project that is intended to connect Galkynysh gas field in Turkmenistan with Kashgar, China, via Uzbekistan and Kyrgyzstan starting in 2016 (Zenn 2013; cf. also Kim and Indeo 2013: 282). Through lessening Kyrgyzstan's dependence on Uzbekistan, the project might contribute to normalised and less contentious relations (Brill Olcott 2013). On all TurkmenistanChina gas projects, Pirani cautions, however, that (1) Ashgabat may want to only gradually increase volumes; (2) Turkmenistan lacks the know-how to raise production in time; and (3) Turkmen gas is actually much more expensive for China, and especially its eastern part, than LNG from several other exporters (cf. Table 1) (2012: 85-86). 
Table 1 Shanghai gas prices, October 2011 (million British thermal unit [mmbtu]; million cubic meters $[\mathrm{mcm}])$

\begin{tabular}{|c|c|c|}
\hline & $\$ / m m b t u$ & $\$ / \mathrm{mcm}$ \\
\hline $\begin{array}{l}\text { Price of Turkmen gas at the Kazakh-Chinese border } \\
\text { (assuming an oil price of } \$ 100 / \text { barrel) }\end{array}$ & 9.1 & 334.0 \\
\hline West-east pipeline II transmission tariff & 4.2 & 154.1 \\
\hline Shanghai city gate (Turkmen gas) & 13.3 & 488.1 \\
\hline Shanghai city gate (Chinese domestic gas) & 9.8 & 359.7 \\
\hline Shanghai city gate (LNG from Malaysia)* & 7.5 & 275.2 \\
\hline $\begin{array}{l}\text { Loss borne by CNPC on sale of Turkmen gas (i.e. price of } \\
\text { Turkmen gas - price of domestic gas) }\end{array}$ & 3.5 & 128.4 \\
\hline \multicolumn{3}{|c|}{$\begin{array}{l}\text { * There is a wide range of prices paid for LNG imports into China, with the price } \\
\text { of Malaysian LNG near the middle. Customs data for October } 2011 \text { shows prices } \\
\text { between } \$ 3.24 / \mathrm{mmbtu} \text { (Australian LNG) and } \$ 19.18 \text { (Egyptian LNG) paid ex-ship, } \\
\text { with re-gasification and transport costs to be added. }\end{array}$} \\
\hline
\end{tabular}

Source: Pirani 2012: 86, citing Michael Chen, Oxford Institute for Energy Studies

Moreover, the Chinese and Tajik presidents met during the September 2013 SCO summit and launched the construction of line $\mathrm{D}$ of the CA-China gas pipeline, which will connect Tajikistan to the new regional gas network (Zenn 2013). Finally, negotiations over a Turkmenistan-Afghanistan-Tajikistan-PRC gas pipeline have begun. This has served as a warning to Kazakhstan that Turkmen gas could be brought to China without crossing its territory, and as a counter-move to Washington's support for the TAPI (Turkmenistan-Afghanistan-Pakistan-India) pipeline project (Pirani 2012: 87). Interestingly, Moscow has begun supporting the TAPI project in an apparent balancing measure (Kim and Indeo 2013: 284).

The latter might have been prompted by the fact that China will receive three times as much gas through the CA-China gas pipeline $(65 \mathrm{bcm} /$ year) than Russia 
will from CA in its entirety (Brill Olcott 2013; cf. also Table 2) and about 50 percent of China's overall consumption at 2010 levels. Moreover, said pipeline and China's intervention in 2009 have destroyed Russia's attempt to coerce Turkmenistan regarding gas pricing. Lastly, the RF is now only the third-largest importer of Turkmen gas, whereas it had been number one until 2009 and now receives only 30 $\mathrm{bcm} /$ year of CA gas instead of the planned $80 \mathrm{bcm} /$ year (Kim and Blank 2013: 783784).

Table 2 CA and Caspian gas exports 2011-2020 (projections)

\begin{tabular}{|l|l|l|l|}
\hline & $\mathbf{2 0 1 1}$ & $\mathbf{2 0 1 5}$ & $\mathbf{2 0 2 0}$ \\
\hline To/through Russia*** & 32.6 & 22.8 & 19.3 \\
\hline To other Central Asia & 4 & 3.9 & 2.1 \\
\hline To China & 15.5 & 44 & 60 \\
\hline To Iran** & 8.6 & 11 & 11 \\
\hline To Georgia & 1.5 & 1.5 & 2 \\
\hline To Turkey & 6.3 & 5.6 & 13 \\
\hline To Europe & 0 & 0.7 & 10 \\
\hline TOTAL & $\mathbf{6 8 . 5}$ & $\mathbf{8 9 . 5}$ & $\mathbf{1 1 7 . 4}$ \\
\hline $\begin{array}{l}\text { Imports**** } \\
\text { producer countries (all to Kazakhstan, aside from } 0.5 \text { Iran to Azerbaijan) }\end{array}$ & 5.3 & 5.5 & 1.9 \\
\hline contractual/physical **including swaps ***mostly to Ukraine ****to the four \\
\hline
\end{tabular}

Source: Pirani 2012: $109^{16}$

Gazprom did, however, succeed in overtaking the existing Kyrgyz gas pipeline network (KyrgyzGaz) in July 2013. It pledged investments and enhanced supply security as well as support in negotiations for lower prices with Kazakhstan and Uzbekistan (Brill Olcott 2013). Moscow also secured co-operation with Kazakhstan

16 Tables 1 and 2 are reproduced exactly as they appear in Pirani 2012, including the various typos, such as the issue of the first note in Table 2_ '* contractual/physical' - not being attached to any item in the table. 
on the joint exploration of the cross-border Imashevskoye gas field (Assenova 2013), and Lukoil agreed to invest another five bn USD in Uzbekistan in the coming five years (RIA Novosti 2013).

\section{CA uranium and nuclear power}

With regard to uranium and nuclear energy, Pascale Massot and Zhan-Ming Chen make the argument that state-to-state relations are still crucial due to concerns about energy security and the lack of an effective spot market and that the PRC has benefited from this fact in the CA region (2013: 4). In the face of significant competition by the RF, India, South Korea, and Japan, 'the Chinese have shown they will often pay above market prices for those mines, companies and other assets that are genuinely rich in natural resources' (ibid.: 7).

Běijīng was already the sixth largest producer of nuclear energy in 2012 and is set to become number three very soon (World Nuclear Association 2013a). It is 'second to none in the world' in its research and development in nuclear technologies according to the World Nuclear Association (2013c) and is on the course of becoming self-sufficient in most aspects of the fuel cycle. At the moment, 17 reactors are in operation, another 30 are under construction, and many more are planned. Also in reactor design and construction, Běijīng has largely reached self-sufficiency (ibid. 2013d). Against this background, the demand for uranium has far exceeded domestic production and major import increases have become necessary. In due course, the PRC has made further inroads in securing uranium imports from Kazakhstan and Uzbekistan.

At the moment, Kazakhstan is considered to hold 12 percent of the world's uranium resources and to have been the number one producer worldwide since 2009with as much as 36.5 percent of global production in 2012-whereas it had been a non-entity up to 2003 (ibid. 2013f). Of the burgeoning exports, China already receives up to 60 percent-in absolute terms, 4,600 tons from January to August 2013 (Voloshin 2013c). In the coming years, Astana plans to also sell value-added fuel instead of only uranium, hoping to provide 30 percent of global fuel fabrication. Once again, the PRC - as confirmed by Kazatomprom and CGNPG - is intended to be one of the main customers. The construction of a nuclear reactor inside Kazakhstan is also being considered (World Nuclear Association 2013f).

In September 2013, Chinese companies, moreover, successfully concluded further agreements with the Uzbek side on co-operation in the uranium field (Zenn 2013). Uzbekistan is now the world's seventh largest uranium supplier and rising (World Nuclear Association 2013b). The Chinese-Uzbek JV Goskomgeo remains the only producer with direct foreign participation, its authorised capital was almost doubled, and it obtained the operating rights regarding a new uranium deposit 
(Voloshin 2013c). Creative ways of securing procurement contracts have been for example (1) exchanging them for holdings in Chinese nuclear power plants or fuel processing facilities (cf. Kazakhstan) and (2) granting interest-free soft loans (cf. Uzbekistan) (Massot and Chen 2013: 8).

The Chinese government does not want to become dependent on these suppliers, however, and plans to be able to supply a third of its uranium demand from domestic sources and another third from overseas holdings of its uranium producers in 2020 (ibid.: 7). It also works to diversify foreign suppliers-next to Kazakhstan and Uzbekistan there are also Mongolia, Namibia, Algeria, Zimbabwe, Australia, and Canada - and to use ever more advanced and fuel-efficient nuclear power systems (ibid.: 7-8). Just within the last few years,

a multi-pronged strategy of engagement in the uranium market [...] has allowed [China] to triple its total uranium imports, and forge ahead with the world's most ambitious civilian nuclear power development plan (ibid.: 8).

It already imports about as much uranium as the US does, although it only has 15 operating reactors compared to the more than 100 in the US (ibid.: 10).

\section{CA hydropower and water security}

Regarding hydropower, the various dam projects remain a source of friction between CA states. Umida Hashimova recounts the on-going problems surrounding the Rogun dam in Tajikistan, which is seen as a threat to Uzbekistan's water security in Tashkent (2013). The Tajik populace in turn has been shown in several polls to see Uzbekistan as a security threat (ibid.). Voloshin confirms the friction caused by hydropower, also between Kyrgyzstan and Kazakhstan (2013a).

In this regard, Roman Muzalevsky brings up a new aspect (2013). The PRC is at the same time faced with growing shortages of renewable freshwater and 'home to the largest number of trans-border river overflows in the world' (ibid.). The Irtysh and Ili rivers, which originate in China, cover a substantial proportion of Kazakh and Siberian (RF) water needs. Should Běijīng decide to use more of those rivers' water itself, or at least tolerate such a trend, this could have a major impact on Kazakhstan for example, even leading to Lake Balkash being split in two.

Concerning Russo-CA projects, Voloshin notes that the RF reaffirmed its support for the Kambarata-1 dam project in Kyrgyzstan in May 2013 (2013a). In September 2012, Moscow secured contracts in the Kyrgyz hydro-energy sector-as well as a 15-year lease for a military base and the termination of the US presence on Manas airbase in July 2014 - in exchange for forgiving 500 million USD in Kyrgyz debt. 


\section{Conclusion: Reviewing predictions}

Looking back at the developments of the last 18 months and how they correspond to the argumentative trends described above, Chinese discourse appears ever more relevant. The need to assuage Russian fears only grows, while China advances even faster than expected into a region that is seen as quintessential to Chinese energy security.

It has become clear that the PRC's engagement of CA's energy sector is proceeding and being managed effectively and is unfolding faster than many predicted, sometimes even ahead of already ambitious plans. It has risen to enormous proportions - although hydropower is lagging - and is already overshadowing that of the RF. China controls decidedly more of Kazakhstan's oil, and it imports decidedly more of Turkmenistan's gas and Kazakhstan's uranium than Russia does. It rapidly expands its pipeline network, and CNPC representatives have already let their Gazprom counterparts know that CA is China's stomping ground now. Whereas China's state energy companies used to be the sole drivers of the expansion, this expansion is now increasingly undergirded by a cohesive political strategy (cf. Silk Road economic belt) and always reinforced by the unmatched financial potency of the Běijīng government, which allows for soft loans, pre-financing, covering other countries' project costs, and massive investments in related and unrelated areas of CA economies. The PRC offers more money without pushing post-Soviet (re-)integration schemes that might raise scepticism from the side of CA governments.

This trend is likely to lead to even stronger resistance from the Kremlin, as CA governments might delay or abandon their participation in Vladimir Putin's (b. 1952) regional integration projects due to concerns about their economic ties with China. Russian complaints and potential counter or balancing measures, such as supporting the US-sponsored TAPI pipeline, will in turn test the PRC's resolve to always consult, coordinate, and compromise with the RF. Chinese leverage is growing with stronger domestic production and increasing Russian financial dependence. Zhōngnánhăi 中南海 (the 'Chinese Kremlin') will likely reinforce co-ordination efforts, especially in the framework of the SCO, and quietly but resolutely push Russia to the side. The prediction of China successfully preventing an open rupture in the foreseeable future (Eder 2014: 136) is still likely to hold true. Predicted longterm challenges (ibid.: 136-137), however, will test the 'strategic partnership' much earlier, since China already overtook Russia as CA's most important partner in both energy and overall economic co-operation. 


\section{LIST OF ABBREVIATIONS}

ASE
bcm
bn
bpd
CA
cf.
CGNPG
CNNC
CNPC
CPC
CSTO
e.g.
ESPO Pipeline
EU
EurAsEC
i.e.
IR
JV
LNG
mcm
mmbtu
MoU
n.
NCOC
ONGC
PLA
PRC
RAO-UES
RF
SCO
Sinopec
SOEs
SU
TAPI pipeline
TJ
TNK-BP
US
USD
UZ

Atomstroyexport (Russian company)

billion cubic meters

billion

barrels per day

Central Asia

compare

China Guangdong Nuclear Power Group

China National Nuclear Corporation

China National Petroleum Corporation

Caspian Pipeline Consortium

Collective Security Treaty Organization

exempli gratia; for example

Eastern Siberia Pacific Ocean oil pipeline

European Union

Eurasian Economic Community

id est; that is

international relations

joint venture

liquefied natural gas

million cubic meters

million British thermal unit

Memorandum of Understanding

footnote

North Caspian Operating Company

Oil and Natural Gas Corporation Limited

People's Liberation Army (of the PRC)

People's Republic of China

Unified Energy System (of the RF)

Russian Federation

Shanghai Cooperation Organisation

China Petroleum \& Chemical Corporation Limited

state-owned enterprises

Soviet Union

Turkmenistan-Afghanistan-Pakistan-India pipeline

Tajikistan

Tyumenskiy Neftyanaya Kompaniya-British Petroleum

United States of America

US dollars

Uzbekistan 


\section{REFERENCES}

Adolf, Matthias. Energiesicherheitspolitik der VR China in der Kaspischen Region. Erdölversorgung aus Zentralasien. Wiesbaden: Springer, 2011

Anceschi, Luca. "External Conditionality, Domestic Insulation and Energy Security: The International Politics of Post-Niyazov Turkmenistan." In China and Eurasia Forum Quarterly, 8/3, 2010, pp. 93-114

Andrews-Speed, Philip, and Sergei Vinogradov. "China's Involvement in Central Asian Petroleum: Convergent or Divergent Interests?” In Asian Survey, 40/2, 2000, pp. 377-397

Apelt, Beate. "Russland und Usbekistan: Sicherheitspolitische und ökonomische Beziehungen." In SWP Stiftung Wissenschaft und Politik, 3, 2008, pp. 3-16

Assenova, Margarita. "Kazakhstan Expands Economic Cooperation with Russia, but Guards Own Interests.” In Eurasia Daily Monitor, 10/207, 18 November 2013, http: //www.jamestown.org/ regions/centralasia/single/?tx_ttnews\%5Btt_news\%5D=41646\&tx_ttnews\%5BbackPid $\% 5 \mathrm{D}=6$ $57 \& \mathrm{cHash}=$ fafa18612db0a946e6ee15186ffdeebe\#.UpN81GT0w79, accessed November 2013

Blank, Stephen. "Can East Asia Dare to Tie Its Energy Security to Russia and Kazakhstan?" In Journal of East Asian Affairs, 21/1, 2007, pp. 93-137

Blank, Stephen. "Moscow Talks Business, Beijing Answers with Geo-Strategy." In China Brief, 13/22, 7 November 2013, http://www.jamestown.org/regions/chinaasiapacific/single/ ?tx ttnews\%5Btt_news\%5D=41596\&tx_ttnews\%5BbackPid\%5D=52\&cHash=63880e8a206cb7d 2 a240f6287b268858\#.UpN8oGT0w79, accessed November 2013

Bosbotinis, James. "Sustaining the Dragon, Dodging the Eagle and Barring the Bear? Assessing the Role and Importance of Central Asia in Chinese National Strategy." In China and Eurasia Forum Quarterly, 8/1, 2010, pp. 65-81

Brill Olcott, Martha. "China's Unmatched Influence in Central Asia." Carnegie Endowment for International Peace, 2013, http://carnegieendowment.org/2013/09/18/china-s-unmatchedinfluence-in-central-asia/gnky, accessed September 2013

Burghart, Daniel. "Playing Chess on the Eurasia Steppe: The State of the Energy 'Game' 10 Years into the New Millennium in Russia and the Near Abroad." In China and Eurasia Forum Quarterly, 8/4, 2010, pp. 79-100

Buszynski, Leszek. "Russia's New Role in Central Asia.” In Asian Survey, 45/4, 2005, pp. 546565

Cabestan, Jean-Pierre. "China's Foreign- and Security-policy Decision-making Processes under Hu Jintao." In Journal of Current Chinese Affairs, 38/3, 2009, pp. 63-97

Chén, Lùlù 沈露璐. “Lùn Zhōng-É guānxī de fāzhăn” 论中俄关系的发展 [Discussing the Development of China-Russia Relations]. In Xiàndài Shāngmào Gōngyè 现代商贸工业 [Modern Commerce and Industry], 17, 2010, pp. 88-89

Chén, Xiànliáng 陈宪良. “Zhōng-É néngyuán hézuò de xiànzhuàng, qiánjǐng fēnxī qǐshì” 中俄能 源合作的现状、前景分析及启示 [Analysis of and Revelations on the Current State of and Prospects for Sino-Russian Energy Co-operation]. In Xībólìyà Yánjiū 西伯利亚研究 [Siberian Studies], 3, 2010, pp. 22-28

Chén, Xiăoqìn 陈小沁. “Shànghăi hézuò zǔzhī kuàngjià nèi de Zhōng-É néngyuán lìyì fēnxî̄” 上海 合作组织框架内的中俄能源利益分析 [Analysis of the Benefits of Sino-Russian Energy Cooperation within the Framework of the Shanghai Co-operation Organisation]. In Guójì Guānxī Xuéyuàn Xuébào 国际关系学院学报 [Journal of the University of International Relations], 5, 2011, pp. 89-94 
Cheng, Joseph Y. S. "Chinese Perceptions of Russian Foreign Policy During the Putin Administration: U.S.-Russia Relations and 'Strategic Triangle' Considerations." In Journal of Current Chinese Affairs, 38/2, 2009, pp. 145-168

Diāo, Xiùhuá ᄀ秀华. “Xīn shìjì zhōng’é néngyuán hézuò” 新世纪中俄能源合作 [Sino-Russian Energy Co-operation in the New Century]. In Xībóliỳà Yánjiū 西伯利亚研究 [Siberian Studies], 1, 2005a, pp. 18-22

Diāo, Xiùhuá フ秀华. “Zhōng’é néngyuán hézuò de qiánjǐng” 中俄能源合作的前景 [Prospects for Sino-Russian Energy Co-operation]. In Xībóliyà Yánjiū 西伯利亚研究 [Siberian Studies], 5, 2005b, pp. 1-3

Dittmer, Lowell. "Central Asia and the Regional Powers." In China and Eurasia Quarterly, 4, 2007 , pp. 7-22

Dorian, James P., Brett Wigdortz, and Dru Gladney. "Central Asia and Xinjiang, China: Emerging Energy, Economic and Ethnic Relations." In Central Asia Survey, 16/4, 1997, pp. 461-486

Downs, Erica S. "Sino-Russian Energy Relations: An Uncertain Courtship." In The Future of China-Russia Relations, edited by James Bellacqua. Lexington: University Press of Kentucky, 2010, pp. 146-175

Eder, Thomas Stephan. China-Russia Relations in Central Asia. Wiesbaden: Springer, 2014

Fán, Lìjūn 樊利钧, Yú Cuìpíng 于翠萍, and Lǐ Yùshùn 李玉顺. “Zhōngyà dìqū gèguó néngyuán hézuò” 中亚地区各国能源合作潜力和前景 [Interstate Energy Co-operation in Central Asia]. In Dōng'ōu Zhōngyà Shìcháng Yánjiū 东欧中亚市场研究 [Eastern Europe and Central Asia Market Studies], 2, 2000, pp. 1-3

Fāng, Yìxián 方奕贤. “Éméi zhōngyà juélì jíqī duì zhōngguó néngyuán ānquán de yǐngxiàng” 俄 美中亚角力及其对中国能源安全的影响 [The Struggle for Central Asia Between Russia and the United States and the Impact on Chinese Energy Security]. In Xībólìyà Yánjiū 西伯利亚研 究 [Siberian Studies], 2, 2008, pp. 1-4

Féng, Yùjūn 冯玉军. “Zhōng'é zài yàtài dìqū de hézuò” 中俄在亚太地区的合作 [Sino-Russian Co-operation in Eurasia]. In Shijiè Jingjì yú Zhèngzhì 世界经济与政治 [World Economics and Politics], 5, 1997, pp. 1-3

Féng, Yùjūn 冯玉军. “Quánlì jiāojiē hòu Éluósī néngyuán zhèngcè zǒuxiàng yú Zhōng-É néngyuán hézuò” 权利交接后俄罗斯能源政策走向与中俄能源合作 [Trends in Russian Energy Policy Since the Transition of Power and Sino-Russian Energy Co-operation]. In Éluósi Yánjiū 俄罗斯研究 [Russian Studies], 4, 2008, pp. 61-66

Fù, Yǒng 傅勇. “Néngyuán yàosù zǔhé yú Zhōng-Méi - Zhōng-É néngyuán zhànlüè hézuò” 能源 要素组合与中美一中俄能源战略合作 [The Key Element of Energy and Sino-American and Sino-Russian Strategic Energy Co-operation]. In Xiàndài Guójì Guānxī 现代国际关系 [Contemporary International Relations], 12, 2009, pp. 40-47

Hán, Lìuá 韩立华. “Zhōng'é néngyuán hézuò ruògān wèntí tànsuǒ” 中俄能源合作若干问题探 索 [Exploring Some Problems Regarding Sino-Russian Energy Co-operation]. In Xībólìyà Yánjiū 西伯利亚研究 [Siberian Studies], 2, 2006, pp. 1-7

Hăo, Ruìbīn 郝瑞涁, and Wáng Wěiyì 王伟毅. “21 Shì̀ zhōngguó shíyóu ānquán yú zhōng’é shíyóu hézuò” 21 世纪中国石油安全与中俄石油合作 [21st-Century Chinese Oil Security and Sino-Russian Oil Co-operation]. In Zhōngguó Kuàngyè 中国矿业 [China Mining Magazine], 3, 2006, pp. 5-8

Hashimova, Umida. "Uzbekistan Resists Falling Under Russia's Economic Hegemony." In Eurasia Daily Monitor, 177, 9 August 2013, http: //www.jamestown.org/regions/centralasia/ single/?tx_ttnews\%5Btt_news\%5D=41453\&tx_ttnews\%5BbackPid\%5D=53\&cHash=496c976 7901a6f54cf6927aa9fee5fbe\#.U1IIt2Q2w78, accessed October 2013 
Hé, Juan 何娟, and Lǐ Pengcheng 李鹏程. “Zhōngguó yú zhōngyà tiānránqì hézuò zhōng de éluósī yīnsù fēnx $\bar{\imath} ”$ 中国与中亚天然气合作中的俄罗斯因素分析 [Analysis of the Russia-Factor in China's Natural Gas Co-operation with Central Asia]. In Zhīshi Jingji 知识经济 [Knowledge Economy], 19, 2010, p. 131

Hé, Lúnzhì 何伦志, Amuti Anwar, and Zhāng Xīnhuā 张新花. “Zhōngguó de Zhōngyà néngyuán fāzhăn cèlüè” 中国的中亚能源发展策略 [China's Energy Development Strategy for Central Asia]. In Shànghăi Jinggì Yánjiū 上海经济研究 [Shànghăi Journal of Economics], 1, 2008, pp. $37-46$

Helmer, John. "Russia, China Clash Over Oil Price, Supply.” In Asia Times Online, 5 May 2011, http: //www.atimes.com/atimes/Central_Asia/ME05Ag01.html, accessed October 2013

Herberg, Mikkal. "Fuelling the Dragon: China's Energy Prospects and International Implications." In Energy and the Transformation of International Relations: Toward a New ProducerConsumer Framework, edited by Andreas Wenger, et al. Oxford: Oxford University Press, 2009, pp. 269-297

Hú, Méixìng 胡梅兴. “Éluósī kòngzhì Zhōngyà néngyuán de xiànzhuàng yú tiăozhàn” 俄罗斯控 制中亚能源的现状与挑战 [The Current Situation and Challenge of Russia's Control Over Central Asian Energy]. In Guójì Zīliào Xìnxī 国际资料信息 [International Data Information], 6, 2010, pp. 4-6

Ibraimov, Sadykzhan. "China-Central Asia Trade Relations: Economic and Social Patterns." In China and Eurasia Forum Quarterly, 7/1, 2009, pp. 47-59

Jiàn, Ài 箭爱. “Zhōng-É néngyuán hézuò de xiànshí yìyì jí tèdiăn fēnxī” 中俄能源合作的现实意 义及特点分析 [Analysis of Significance and Characteristics of the Realization of SinoRussian Energy Co-operation]. In Shănxī Guófáng Gōngyè Zhíyè Jishù Xuéyuàn Xuébào 陕西 国防工业职业技术学院学报 [Journal of the Shănxī Institute of Technology], 20, 2009, pp. 13

Kassenova, Togzhan. "Uranium Production and Nuclear Energy in Central Asia: Assessment of Security Challenges and Risks." In China and Eurasia Forum Quarterly, 8/2, 2010, pp. 221241

Khodzhaev, Ablat. "The Central Asian Policy of the People's Republic of China." In China and Eurasia Forum Quarterly, 7/1, 2009, pp. 9-28

Kim, Alexander. "China and Kazakhstan: Inevitability of Beijing's Growing Influence." In Eurasia Daily Monitor, 10/153, 16 August 2013, http://www.jamestown.org/regions/ centralasia/single/?tx_ttnews\%5Btt_news\%5D=41289\&tx_ttnews $\% 5 \mathrm{BbackPid} \% 5 \mathrm{D}=657 \& \mathrm{cHash}=98$ b687aae4930331b0d518ba4cea62a1\#.UkiVEGQ2w78, accessed October 2013

Kim, Younkyoo, and Fabio Indeo. "The New Great Game in Central Asia Post 2014: The US 'New Silk Road' Strategy and Sino-Russian Rivalry." In Communist and Post-Communist Studies, 46/2, 2013, pp. 275-286

Kim, Younkyoo, and Stephen Blank. "Same Bed, Different Dreams: China's 'Peaceful Rise' and Sino-Russian Rivalry in Central Asia.” In Journal of Contemporary China, 22/83, 2013, pp. 773-790

Kozyrev, Vitaly. "China's Continental Energy Strategy: Russia and Central Asia.” In China's Energy Strategy: The Impact on Beijing's Maritime Policies, edited by Gabrielle B. Collins, et al. Annapolis MD: Naval Institute Press, 2008.

Láng, Yìhuán 郎一环, and Wáng Lǐmào 王礼茂. “Shíyóu dìyuán zhèngzhì géjú de yănbiàn tàishì jí zhōngguó de zhèngcè xiăngyìng” 石油地缘政治格局的演变态势及中国的政策响应 [The Evolving Situation of Petroleum Geopolitics and China's Policy Response]. In Zìyuán Kēxué 资源科学 [Resources Science], 12, 2008, pp. 1778-1783 
Lǐ, Xìng 李兴. “Lùn Éluósī de néngyuán wàijiāo yú Zhōng-É guānxī zhōng de yóuqì yīnsù” 论俄 罗斯的能源外交与中俄关系中的油气因素 [Discussing Russian Energy Diplomacy and the Oil and Gas Factor in Sino-Russian Relations]. In Éluósī Zhōngyà Dōng'ōu Shicháng 俄罗斯 中亚东欧市场 [Russian, Central Asian and East European Market], 2, 2005, pp. 1-5

Liǔ, Fēnghuá 柳丰华. “Zhōngguó zài zhōngyà: zhèngcè de yănbiàn” 中国在中亚: 政策的演变 [China in Central Asia: Changing Policies]. In Éluósī Zhōngyà Dōng'ōu Yánjīū 俄罗斯中亚东 欧研究 [Russian, Central Asian and East European Studies], 6, 2007, pp. 63-72

Liú, Xiăolíng 刘晓玲. “Éméi zhōngyà lǐhăi dìqū néngyuán bóyì fēnxī” 俄美中亚里海地区能源博 恋分析 [Analysis of the Energy Game Between Russia and the United States in Central Asia and the Caspian Region]. In Éluósī Zhōngyà Dōng'ōu Shìcháng 俄罗斯中亚东欧市场 [Russian, Central Asian and East European Market], 12, 2006, pp. 18-22

Liú, Yǒngwéi 刘勇为. “Guójì jīnróng wēijī yǐngxiàng xià de éluósī duì huá zhànlüè tiáozhěng 国 际金融危机影响下的俄罗斯对华战略调整 [Russia’s Adjustment of Its Policy Towards China under the Influence of the International Financial Crisis]. In Éluósī Yánjiū 俄罗斯研究 [Russian Studies], 2, 2010, pp. 27-39

Lo Bobo. Axis of Convenience: Moscow, Beijing, and the New Geopolitics. Washington and London: Brookings Institution Press and Chatham House, 2008

Marciacq, Florent. "Sino-Russian Geopolitical \& Geo-economic Rapprochement: Strategic Convergence or Tactical Alignment? A Liberal-Constructivist Analysis.” M.A. thesis, Vienna Diplomatic Academy, 2009

Massot, Pascale, and Zhan-Ming Chen. "China and the Global Uranium Market: Prospects for Peaceful Coexistence.” In The Scientific World Journal, 2013, pp. 1-11

Muzalevsky, Roman. "China's Development Plans in Xinjiang Threaten Kazakhstan's Water Security.” In Eurasia Daily Monitor, 160, 11 September 2013, http: //www.jamestown.org /regions/centralasia/single/?tx_ttnews\%5Btt_news\%5D=41345\&tx_ttnews\%5BbackPid\%5D= 657\&cHash=bb370bf71c46c0791fb5a8f8a73165b1\#.UkiVDWQ2w78, accessed October 2013

Neff, Andrew. "China Competing with Russia for Central Asian Investments." In Oil \& Gas Journal, 104/9, 2006, pp. 41-46

Overland, Indra, and Kyrre Elvenes Braekhus. "Chinese Perspectives on Russian Oil and Gas." In Russian Energy Power and Foreign Relations: Implications for Conflict and Co-operation, edited by Jeronim Perovic, et al. Oxon and New York: Routledge, 2009, pp. 201-221

Pān, Guāng 潘光. "Dāngqián Zhōngyà jīngjì ānquán xíngshì jíqī duì Shànghăi Hézuò Zǔzhī de yingxiang” 当前中亚经济安全形势及其对上海合作组织的影响 [Present Energy Security Situation in Central Asia and Its Influence on the SCO]. In Guóji Wèntí Yánjiū 国际问题研究 [China International Studies], 6, 2011, pp. 61-68

Petersen, Alexandros. "Inadvertent Empire.” In The Gadfly, 16 April 2013a, http: //chinaincentralasia.com/2013/04/16/inadvertent-empire/, accessed October 2013

Petersen, Alexandros. "Russia's Energy Bully Takes a Fall." In Foreign Policy, 6 May 2013b, http: //chinaincentralasia.com/2013/05/09/russias-energy-bully-takes-a-fall/, accessed October 2013

Petersen, Alexandros. “Central Asia's New Energy Giant: China.” In The Atlantic, 28 June 2013c, http: //chinaincentralasia.com/2013/06/29/central-asias-new-energy-giant-china/, accessed October 2013

Peyrouse, Sebastien. "The Hydroelectric Sector in Central Asia and the Growing Role of China." In China and Eurasia Forum Quarterly, 5/2, 2007, pp. 131-148

Pirani, Simon. "Review: Marketos, Thrassy (2009), 'China's Energy Geopolitics: The Shanghai Cooperation Organization and Central Asia." In Central Asian Survey, 30/1, 2011, pp. 172175 
Pirani, Simon. "Central Asian and Caspian Gas Production and the Constraints on Export." Oxford Institute of Energy Studies NG 69, 2012

Pomfret, Richard. "Exploiting Energy and Mineral Resources in Central Asia, Azerbaijan and Mongolia." In Research Paper at The University of Adelaide, 16, 2010, pp. 1-22

Qì, Wénhăi 戚文海. “Miànxiàng 21 shìjì de Zhōng-É néngyuán hézuò” 面向 21 世纪的中俄能源 合作 [Sino-Russian Energy Co-operation Towards the 21st Century]. In Dōng'ōu Zhōngyà Shicháng Yánjiū 东欧中亚市场研究 [Eastern Europe and Central Asia Market Studies], 11, 1998, pp. 1-5

Qián, Juān 钱娟. “Qiănxī Zhōngguó zài Zhōngyà dìqū de néngyuán ānquán zhànlüè” 浅析中国在 中亚地区的能源安全战略 [Analysis of China's Energy Security Strategy in Central Asia]. In Shìjì Qiáo 世纪桥 [Century Bridge], 3, 2011, pp. 85-86

RIA Novosti. "LUKoil to Invest \$5Bln in Uzbekistan Projects," 4 December 2013, http: //en.ria.ru/business/20131204/185256692/LUKoil-to-Invest-5Bln-in-Uzbekistan-Projects.html ?goback=\%2Egde_135866_member_5814596406396080132\#\%21, accessed December 2013

Rousseau, Richard. "Kazakhstan: Continuous Improvement or Stalemate in Its Relations with China?” In Strategic Analysis, 37/1, 2013, pp. 40-51

Saurbek, Zhanibek. "Kazakh-Chinese Energy Relations: Economic Pragmatism or Political Cooperation?" In China and Eurasia Forum Quarterly, 6/1, 2008, pp. 79-93

Schmidt-Glintzer, Helwig. Das neue China. Von den Opiumkriegen bis heute, 2nd ed. München: C. H. Beck, 2001

Schmitz, Andrea. "Partner aus Kalkül. Russland in Zentralasien." In SWP Stiftung Wissenschaft und Politik, 3, 2008, pp. 5-29

Sethuraman, Dinakar, and Stephen Bierman. "China Turns to Turkmen Natural Gas as Gazprom Seeks Price, Pipeline Deal.” In Bloomberg News, 3 April 2011, http: //www.bloomberg.com/ news/2011-03-03/china-may-increase-gas-purchase-from-\%20turkmenistan-ministersays.html, accessed December 2013

Sheives, Kevin. "China Turns West: Beijing's Strategy Towards Central Asia.” In Pacific Affairs, 79/2, 2006, pp. 205-224

Shǐ, Chūnyáng 史春阳. “Hòu jīnróng wēijī shídài de Zhōng-É néngyuán hézuò” 后金融危机时代 中俄能源合作 [Sino-Russian Energy Co-operation after the Financial Crisis]. In Éluósī Zhōngyà Dōng'ōu Shicháng 俄罗斯中亚东欧市场 [Russian, Central Asian and East European Market], 6, 2011, pp. 46-51

Shí, Zé 石泽. “Lǐhăi dìqū néngyuán kāifā qiánjǐng jí yǐngxiàng” 里海地区能源开发前景及影响 [Current State and Consequences of Energy Exploration at the Caspian Sea]. In Guóji Wèntí Yánjiū 国际问题研究 [China International Studies], 2, 1998, pp. 1-7

Shí, Zé 石泽. “Biànhuà zhōng de zhōngyà jíqī zŏushì” 变化中的中亚及其走势 [The Changing Central Asia and Trends for Its Further Development]. In Guójì Wèntí Yánjiü 国际问题研究 [China International Studies], 2, 2005, pp. 37-41

Shí, Zé 石泽. “Shilun quanfangwei fazhan de zhongguo yu zhongya guojia guanxi” 试论全方位 发展的中国与中亚国家关系 [Some Comments on the Overall Development of China's Relations with Central Asian Countries]. In Lìlùn Cānkăo 理论参考 [Theory Reference], 5, 2007, pp. $48-50$.

Socor, Vladimir. "China to Increase Central Asian Gas Imports Through Multiple Pipelines." In Eurasia Daily Monitor, 152, 9 August 2012, http: //www.jamestown.org/regions/centralasia/single/?tx_ttnews\%5Btt_news\%5D=39751\&tx_ttnews\%5BbackPid\%5D=661\&cHash=c53 c4b6c03bc25be36581996bf144c19\#.UkiV-2Q2w78, accessed October 2013 
Socor, Vladimir. "Kazakhstan's Kashagan Oil Project Set to Start Commercial Production." In Eurasia Daily Monitor, 166, 19 September 2013, http://www.jamestown.org/regions/centralasia/single/?tx_ttnews\%5Btt_news\%5D $=41386 \&$ tx_ttnews $\% 5 \mathrm{BbackPid} \% 5 \mathrm{D}=53 \& \mathrm{cHash}=210 \mathrm{e}$ b1d49b42b6fbf7d9f5c8c3204e7f\#.UkgxfmQ2w78, accessed September 2013

Sūn, Língyún 孙凌云. “Zhōngyà guójiā de néngyuán kāifā yú zhèngcè” 中亚国家的能源开发与 政策 [The CA Countries' Energy Exploitation and Policy]. In Éluósī Zhōngyà Dōng'ōu Shicháng 俄罗斯中亚东欧市场 [Russian, Central Asian and East European Market], 10, 2004, pp. 16-19

Sūn, Yǒngxiáng 孙永祥. “É quánqiú néngyuán ānquán zhèngcè kăoliang jí Zhōng-É néngyuán hézuò” 俄全球能源安全政策考量及中俄能源合作 [Examination of Russia's Global Energy Security Policy and Sino-Russian Energy Co-operation]. In Éluósī Zhōngyà Dōng'ōu Shìcháng 俄罗斯中亚东欧市场 [Russian, Central Asian and East European Market], 2, 2010, pp. 1-5

Voloshin, Georgiy. "Central Asia's Unresolved Bilateral Disputes as a Challenge to Fruitful Security Cooperation.” In Eurasia Daily Monitor, 143, 2 August 2013a, http://www.james town.org/regions/centralasia/single/?tx_ttnews\%5Btt_news\%5D=41216\&tx_ttnews\%5Bback $\mathrm{Pid} \% 5 \mathrm{D}=657 \& \mathrm{cHash}=$ fae0fb8980f6f737e1f0764cd5c29cf0\#.UkiVGWQ2w78, accessed October 2013

Voloshin, Georgiy. "China Strengthens Its Hand in Kazakhstan After Xi Jinping's Visit." In Eurasia Daily Monitor, 164, 17 September 2013b, http:/www.jamestown.org/regions/centralasia/single/?tx_ttnews\%5Btt_news\%5D=41368\&tx_ttnews\%5BbackPid\%5D=53\&cHash=b5 192b1a4df6b00cf9a069005eb96e10\#.UkgxyWQ2w78, accessed September 2013

Voloshin, Georgiy. "India Looses out to China in Central Asia's Uranium Competition." In Eurasia Daily Monitor, 183, 15 October 2013c, http://www.jamestown.org/regions/centralasia/single/?tx_ttnews\%5Btt_news\%5D=41489\&tx_ttnews\%5BbackPid $\% 5 \mathrm{D}=657 \& \mathrm{cHash}=\mathrm{dfa}$ a8a5075cac037d0a59432d1606142\#.UpN81GT0w79, accessed November 2013

Wáng, Hăiyùn 王海运. “Duōshìjiăo tòushì Zhōng-É-Hā néngyuán hézuò hóngguān huánjìng” 多 视角透视中俄哈能源合作的宏观环境 [Looking at the Macro-Environment of Sino-RussianKazakh Energy Co-operation from Different Angles]. In Zhōngguó Shíyóu Shíhuà 中国石油 石化 [China Petroleum], 24, 2006, pp. 20-21

Wáng, Hăiyùn 王海运. “Zhong-É guānxī: zhànlüè jīchǔ yú fāzhăn qūshì” 中俄关系:战略基础与 发展趋势 [Sino-Russian Relations: Strategic Basis and Development Trends]. In Éluósī Yán$j i \bar{u}$ 俄罗斯研究 [Russian Studies], 2, 2009, pp. 3-9

Wáng, Hăiyùn 王海运. “Zhōng-É néngyuán hézuò de yǒulì yīnsù yú zhìyuè yīnsù” 中俄能源合作 的有利因素与制约因素 [Favourable Factors and Restraints in Sino-Russian Energy Cooperation]. In Éluósī Xuékān 俄罗斯学刊 [Russian Studies], 3, 2011, pp. 5-9

Wáng, Xiăoméi 王晓梅. “Zhōngyà shíyóu hézuò yú zhōngguó néngyuán ānquán zhànlüè” 中亚石 油合作与 中国能源安全战略 [Central Asian Oil Co-operation and China’s Energy Security Strategy]. In Guójì Jingjì Hézuò 国际经济合作 [International Economic Co-operation], 6, 2008, pp. 41-46

Wesner, Friederike, and Anne J. Braun. "Chinas Energiediplomatie: Kooperation oder Konkurrenz in Asien?” In SWP Stiftung Wissenschaft und Politik, 5, 2006, pp. 1-8

Wilson, Jeanne L. Strategic Partners: Russian-Chinese Relations in the Post-Soviet Era. Armonk: M. E. Sharpe, 2004

Wishnick, Elizabeth. Mending Fences: The Evolution of Moscow's China Policy from Brezhnev to Yeltsin. Seattle: University of Washington Press, 2001

World Nuclear Association. "Nuclear Share Figures, 2002-2012." Information Library, updated May 2013a, http: //world-nuclear.org/info/Facts-and-Figures/Nuclear-generation-by-country/, accessed December 2013 
World Nuclear Association. "Uzbekistan Uranium.” Information Library, updated October 2013b, http: //www.world-nuclear.org/info/Country-Profiles/Countries-T-Z/Uzbekistan/, accessed December 2013

World Nuclear Association. “China's Nuclear Fuel Cycle.” Information Library, updated November 2013c, http: //world-nuclear.org/info/Country-Profiles/Countries-A-F/China--NuclearFuel-Cycle/, accessed December 2013

World Nuclear Association. "Nuclear Power in China." Information Library, updated November 2013d, http: //world-nuclear.org/info/Country-Profiles/Countries-A-F/China--Nuclear-Power/, accessed December 2013

World Nuclear Association. "Nuclear Power in Russia." Information Library, updated November 2013e, http: //www.world-nuclear.org/info/Country-Profiles/Countries-O-S/Russia--NuclearPower/, accessed December 2013

World Nuclear Association. "Uranium and Nuclear Power in Kazakhstan." Information Library, updated November 2013f, http: //world-nuclear.org/info/Country-Profiles/Countries-GN/Kazakhstan/, accessed December 2013

World Nuclear News. "Construction Begins on Tianwan 4.” New Nuclear, 27 September 2013, http: //www.world-nuclear-news.org/NN-Construction_begins_on_Tianwan_4-2709134.html, accessed December 2013

Wú, Dàhuī 吴大辉. “2010 nián Éluósī duìwài zhèngcè: jìnzhăn yú wèntí” 2010 年俄罗斯对外政 策: 进展与问题 [Russian Foreign Policy in 2010: Progress and Problems]. In Héping yú Fāzhăn 和平与发展 [Peace and Development], 2, 2011, pp. 9-14

Wú, Ēnyuán 吴恩远. “Zhōng É Méi Ōu yú Zhōngyà guójiā néngyuán hézuò xiànzhuàng jí qiánjǔng” 中俄美欧与中亚国家能源合作现状及前景 [Current State of and Prospects for Energy Co-operation in Central Asia Between China, Russia, the United States and the European Union]. In Guójì Shíyóu Jīngjì 国际石油经济 [International Petroleum Economics], 11, 2009, pp. 31-33

Xià, Yìshàn 夏义善. “Zhōng-É néngyuán hézuò de xiànzhuàng hé qiánjīng” 中俄能源合作的现 状和前景 [Current State of and Prospects for Sino-Russian Energy Co-operation]. In Hépíng yú Fāzhăn 和平与发展 [Peace and Development], 3, 2007, pp. 5-8

Xú, Déróng 徐德荣 and Wáng Yán 王岩. “Lùn Zhōng-É shíyóu hézuò de zhìyuē yīnsù” 论中俄石 油合作的制约因素 [Considering Constraining Factors in Sino-Russian Oil Co-operation]. In Xībólìyà Yánjiū 西伯利亚研究 [Siberian Studies], 6, 2009, pp. 17-21

Xú, Xiăojié 徐小杰, Chéng Jiàn 成健, and Wáng Yěqí 王也琪. “Éluósī néngyuán zhànlüè tiáozhěng yú zhōng'é yóuqì zhànlüè hézuò” 俄罗斯能源战略调整与中俄油气战略合作 [Russia's Adjustment of Its Energy Strategy and Sino-Russian Strategic Oil and Gas Co-operation]. In Éluósī Yánjiū 俄罗斯研究 [Russian Studies], 2, 2007, pp. 54-58

Yáng, Chéng 杨成. “Zhìdù lěijī yú zhōng’é guānxī de zhōngchángqī qiánjǐng” 制度累积与中俄关 系的中长期前景 [Systematization and Mid- to Long-term Prospects for Sino-Russian Relations]. In Éluósī Yánjīu 俄罗斯研究 [Russian Studies], 3, 2007, pp. 16-23

Yáng, Léi 杨雷. “Zhōngyà júshì de xiànzhuàng yú qiánjǐng” 中亚局势的现状与前景 [Central Asia. Current Situation and Outlook]. In Xiàndài Guójì Guānxī 现代国际关系 [Contemporary International Relations], 3, 2010, pp. 32-37

Yáng, Wénlán 杨文兰. “Zhōng-É néngyuán hézuò xiànzhuàng jí fāzhăn wèntí yánjiū” 中俄能源 合作现状及发展问题研究 [Study of Sino- Russian Energy Co-operation and Problems for Its Development]. In Nèimēnggŭ Cáijīngxuéyuàn Xuébào 内蒙古财经学院学报 [Journal of Inner Mongolia University of Finance and Economics], 4, 2010, pp. 9-14

Yu Bin. "In Search for a Normal Relationship: China and Russia into the 21st Century." In China and Eurasia Forum Quarterly, 5/4, 2007, pp. 47-81 
Yú, Cuìpíng 于翠萍. “Lùn zhōngyà dìqū néngyuán hézuò de qiánlì hé qiánjǐng” 论中亚地区能源 合作的潜力和前景 [Discussing Energy Co-operation in the Central Asian Region: Potential and Prospects]. In Guóji Shíyóu Jingjì 国际石油经济 [International Petroleum Economics], 3, 2000, pp. 35-36

Yú, Yáng 于扬. “Lùn éluósī de néngyuán jīngjì wàijiāo zhànlüè yú zhōng’é néngyuán hézuò” 论 俄罗斯的能源经济外交战略与中俄能源合作 [Discussing Russia's Energy Economy Foreign Policy Strategy and Sino-Russian Energy Co-operation]. In Shídài Jingmào 时代经贸 [Economic and Trade Update], 5, 2007, pp. 34-35

Zenn, Jacob. "China and the SCO: Dead Wood but a Good Platform." In China Brief, 20, 10 October 2013, http: //www.jamestown.org/regions/centralasia/single/?tx_ttnews\%5Btt_news $\% 5 \mathrm{D}=41471 \&$ tx_ttnews $\% 5 \mathrm{BbackPid} \% 5 \mathrm{D}=53 \& \mathrm{cHash}=\mathrm{c} 18016 \mathrm{a} 7 \mathrm{f} 25186 \mathrm{bc} 2 \mathrm{bee} 813 \mathrm{f} 4 \mathrm{~d} 93 \mathrm{be} 4 \mathrm{~b}$ \#.U11IjWQ2w78, accessed October 2013

Zhāng, Yào 张耀. “Zhōngguó yú Zhōngyà guójiā de néngyuán hézuò jí zhōngguó de néngyuán ānquán - dìyuán zhèngzhì shìjiāo de fēnxî” 中国与中亚国家的能源合作及中国的能源安 全一地缘政治视角的分析 [Energy Co-operation Between China and the Central Asian States and Chinese Energy Security-A Geopolitical Analysis]. In Éluósī Yánjiū 俄罗斯研究 [Russian Studies], 6, 2009, pp. 116-128

Zhāng, Yè 张晔. "Zhōngyà dìqū de dàguó juézhú jí duì Zhōngguó yú Zhōngyà qūyù jīngjì hézuò de yǐngxiàng” 中亚地区的大国角逐及对中国与中亚区域经济合作的影响 [Competition of Great Powers in Central Asia and Its Influence on China's Economic Co-operation with Central Asia]. In Xīnjiāng Shèhuì Kẽxué 新疆社会科学 [Social Sciences in Xīnjiāng], 3, 2009, p. 15

Zhào, Huáshēng 赵华胜. “Zhōngyà yú dàguó guanxi” 中亚与大国关系 [Central Asia and Big Power Relations]. In Guójì Guānchá 国际观察 [International Review], 3, 2008, pp. 1-8

Zhào, Huáshēng 赵华胜. “Zhōng-É guānxī zhōng de Shànghǎi Hézuò Zǔzhī” 中俄关系中的上海 合作组织 [The SCO in Sino-Russian Relations]. In Hépíng yú Fāzhăn 和平与发展 [Peace and Development], 2, 2010, pp. 37-42

Zhào, Huáshēng 赵华胜. “Tòuxī Eluósī yú Shànghăi Hézuò Zǔzhī guanxi” 透析俄罗斯与上海合 作组织关系 [Analysing Russia’s Relations with the SCO]. In Guójì Wèntí Yánjiū 国际问题研 究 [China International Studies], 1, 2011, pp. 15-23, 51

Zhào, Míngwén 赵鸣文. “2009 nián Zhōngyà guójiā jīngjì xíngshì yú duì Huà guānxī” 2009 年中 亚国家经济形势与对华关系 [The Economic Situation in CA States in 2009 and Relations with China]. In Héping yú Fāzhăn 和平与发展 [Peace and Development], 3, 2010a, pp. 59-65

Zhào, Míngwén 赵鸣文. “Nijìng zhōng de Zhōngguó tóng Zhōngyà guójiā guanxi” 逆境中的中国 同中亚国家关系 [Unfavourable Conditions for Sino-Central Asian Relations]. In Éluósī Zhōngyà Dōng'ōu Shìcháng 俄罗斯中亚东欧市场 [Russian, Central Asian and East European Market], 8, 2010b, pp. 1-8

Zhào, Míngwén 赵鸣文. “Zhōng-É guānxī jìnrù xīn de lìshǐ fāzhăn shíqî” 中俄关系进入新的历 史发展时期 [Sino-Russian Relations Enter a New Period of Historic Development]. In Éluósī Zhōngyà Dōng'ōu Yánjiū 俄罗斯中亚东欧研究 [Russian, Central Asian and East European Studies], 1, 2010c, pp. 62-67

Zhào, Míngwén 赵鸣文. “Zhōng-É guānxī de fāzhăn jí zhănwăng” 中俄关系的发展及展望 [Sino-Russian Relations: Development and Outlook]. In Hépíng yú Fāzhăn 和平与发展 [Peace and Development], 2, 2011, pp. 36- 42

Zhōu, Yánlì 周延丽. “Zhōng-É néngyuán hézuò fāzhăn qiánjǐng fēnxī” 中俄能源合作发展前景 分析 [Analysis of the Prospects for the Development of Sino-Russian Energy Co-operation]. In Éluósī Zhōngyà Dōng'ouu Shìcháng 俄罗斯中亚东欧市场 [Russian, Central Asian and East European Market], 2, 2006, pp. 39-42 
Zhōu, Yánlì 周延丽, and Wáng Bīngyín 王兵银. “Zhōng-É néngyuán hézuò xíngshì fēnx̄̄” 中俄 能源合作形势分析 [Analysis of Sino-Russian Energy Relations]. In Xībólìyà Yánjiū 西伯利 亚研究 [Siberian Studies], 6, 2009, pp. 5-9

Ziegler, Charles E. "Competing for Markets and Influence: Asian National Oil Companies in Eurasia." In Asian Perspective, 32/1, 2008, pp. 129-163

Ziegler, Charles E. "Russia and the CIS in 2008: Axis of Authoritarianism?" In Asian Survey, 49/1, 2009, pp. 135-145 


\section{GLOSSARY}

\author{
bàquán zhùyì \\ Běijīnng \\ Cháng'ān \\ Chén Lùlù \\ dānbiān zhùyì \\ Dàqìng
}

Dèng Xiăopíng

Hēilóngjiāng

Jiāngsū

Jiāngsū hēdiàn yǒuxiàn gōngsī

lěngzhàn sīwéi

lüèduō

Máo Zédōng

néngyuán zhímíndì

Sānxiá dàbà

Shănxī

shìlì fànwéi sīwéi

Tiánwān

Wūlǔmùqí

$X_{\overline{1}}{ }^{\prime} a ̄ n$

xiăozú

xīfānghuà

Xí Jìnpíng

Xīnjiāng

Yáng Wénlán

yuánliào fùyōng

zhànlüè shībài

Zhōngguó guăngdōng hédiàn

jítuán

Zhōngguó hégōngyè jítuán

gōngsī

Zhōngguó shíyóu tiānránqì jítuán gōngsī

Zhōngnánhăi
霸权主义
北京
长安
沈露璐
单边主义
大庆

邓小平

黑龙江

江苏

江苏核电有限公司

冷战思维

掠夺

毛泽东

能源殖民地

三峡大坝

陕西

势力范围思维

田湾

乌鲁木齐

西安

小组

西方化

习近平

新疆

杨文兰

原料附庸

战略失败

中国广东核电集团

中国核工业集团公司

中国石油天然气集团

公司

中南海 hegemonism

capital of the PRC

old name of Xī'ān (see below)

scholar and author

unilateralism

Chinese city in Hēilóngjiāng

Province (end point of ESPO

pipeline)

former leader of the PRC (19041997)

name of a Chinese province

name of a Chinese province

Jiāngsū Nuclear Power Corporation

Cold War thinking

plunder(ed)

former leader of the PRC (18931976)

resource colony

name of a nuclear power plant

name of a Chinese province

Three Gorges Dam

sphere of influence thinking

Ürümqi, capital of Xīnjiāng

Autonomous Region

Chinese city, capital of Shănxi

Province

small-groups (political unit)

Westernization

current president of the PRC and General Secretary of the CPC (b. 1953)

name of a Chinese Autonomous

Region

scholar and author

raw material dependency

strategic defeat

CGNPG

CNNC

CNPC

seat of the PRC's Government 